\title{
High resolution cyclostratigraphy of the early Eocene - new insights into the origin of the Cenozoic cooling trend
}

\author{
T. Westerhold and U. Röhl \\ MARUM - Center for Marine Environmental Sciences, University of Bremen, Leobener Strasse, 28359 Bremen, Germany
}

Received: 22 December 2008 - Published in Clim. Past Discuss.: 23 February 2009

Revised: 5 June 2009 - Accepted: 25 June 2009 - Published: 6 July 2009

\begin{abstract}
Here we present a high-resolution cyclostratigraphy based on X-ray fluorescence (XRF) core scanning data from a new record retrieved from the tropical western Atlantic (Demerara Rise, ODP Leg 207, Site 1258). The Eocene sediments from ODP Site 1258 cover magnetochrons $\mathrm{C} 20$ to $\mathrm{C} 24$ and show well developed cycles. This record includes the missing interval for reevaluating the early Eocene part of the Geomagnetic Polarity Time Scale (GPTS), also providing key aspects for reconstructing high-resolution climate variability during the Early Eocene Climatic Optimum (EECO). Detailed spectral analysis demonstrates that early Eocene sedimentary cycles are characterized by precession frequencies modulated by short $(100 \mathrm{kyr})$ and long (405 kyr) eccentricity with a generally minor obliquity component. Counting of both the precession and eccentricity cycles results in revised estimates for the duration of magnetochrons C21r through C24n. Our cyclostratigraphic framework also corroborates that the geochronology of the Eocene Green River Formation (Wyoming, USA) is still questionable mainly due to the uncertain correlation of the "Sixth tuff" to the GPTS.

Right at the onset of the long-term Cenozoic cooling trend the dominant eccentricity-modulated precession cycles of ODP Site 1258 are interrupted by strong obliquity cycles for a period of $\sim 800 \mathrm{kyr}$ in the middle of magnetochron $\mathrm{C} 22 \mathrm{r}$. These distinct obliquity cycles at this low latitude site point to (1) a high-latitude driving mechanism on global climate variability from 50.1 to $49.4 \mathrm{Ma}$, and (2) seem to coincide with a significant drop in atmospheric $\mathrm{CO}_{2}$ concentration below a critical threshold between 2- and 3-times the preindustrial level (PAL). The here newly identified orbital configuration of low eccentricity in combination with high obliquity amplitudes during this $\sim 800$-kyr period and the crossing
\end{abstract}

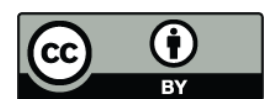

Correspondence to: $\mathrm{T}$. Westerhold (twesterhold@marum.de) of a critical $p \mathrm{CO}_{2}$ threshold may have led to the formation of the first ephemeral ice sheet on Antarctica as early as $\sim 50 \mathrm{Ma}$ ago.

\section{Introduction}

The calibration of the standard Geomagnetic Polarity Time Scale (GPTS) for the Eocene is based primarily on radioisotopic (e.g., ${ }^{40} \mathrm{Ar} /{ }^{39} \mathrm{Ar}$ ) dating (Luterbacher et al., 2004). Relatively large uncertainties in radiometric age constraints and the selection of tie points itself can result in different versions of the GPTS (Machlus et al., 2004). Particularly, the early Eocene interval from the Paleocene-Eocene boundary to the top of magnetochron C21n in the GPTS of Cande and Kent $(1992,1995)$ ("CK95") is 1.7 myr shorter than the same interval in the Geological Time Scale 2004 (GPTS2004, Ogg and Smith, 2004; Gradstein et al., 2004). This discrepancy results from an $\sim 800$-kyr difference in the radiometric age for the identical tuff within magnetochron $\mathrm{C} 21 \mathrm{n}(.33)$ and an $\sim 800$-kyr difference in the absolute age for the Paleocene-Eocene boundary. Recalibration of the C23C22 transition in the Green River Formation in Wyoming (USA) using a new radiometric age tie point ("Sixth tuff") (Machlus et al., 2004; Smith et al., 2006) even resulted in a $\sim 4$ myr longer duration of the interval from the P-E boundary to the top of C21n than the previous estimates by CK95. The recalibration of the C23-C22 transition by dated ash layers from the Green River Formation (Machlus et al., 2004; Smith et al., 2006) is questionable, however, because of the controversial correlations within the Green River Formation (Smith et al., 2003, 2004, 2006; Clyde et al., 2001, 2004) and the uncertain positioning of the Sixth tuff with respect to magnetostratigraphy.

The cyclic early Paleogene sediments recovered during Ocean Drilling Program (ODP) Leg 208 (Walvis Ridge, S. Atlantic) have been used to construct an orbitally

Published by Copernicus Publications on behalf of the European Geosciences Union. 
calibrated, but still floating time scale covering the Paleocene and earliest Eocene from $\sim 58$ to $\sim 53.5 \mathrm{Ma}$ (Westerhold et al., 2007). This cyclostratigraphy provided a very robust estimate for the duration of $\mathrm{C} 24 \mathrm{r}$, including the exact relative position of the P-E boundary within C24r. So far, the only cyclostratigraphic study from marine sediment cores (ODP Site 1051) in the Ypresian Stage covers magnetochrons C24 to C22r (Röhl et al., 2003).

Here we present a high-resolution cyclostratigraphy based on X-ray fluorescence (XRF) core-scanning data from the tropical western Atlantic sediments (Demerara Rise, ODP Leg 207, Site 1258). Eocene sediments of Site 1258 consist of nannofossil chalk with foraminifers, which exhibit extremely well developed cycles covering the interval from magnetochron $\mathrm{C} 20$ to $\mathrm{C} 24$. These data have been used to construct an orbitally calibrated chronostratigraphy for the early to middle Eocene in order to revise and evaluate the early to middle Eocene GPTS. Moreover, the cyclic sedimentary succession has high potential to provide important insight into the climatic evolution of the early to middle Eocene. This period is of special interest because it encompasses the Early Eocene Climate Optimum (EECO; Zachos et al., 2001), the interval with the highest global temperature recorded in the past $70 \mathrm{Ma}$, and also marks the beginning of the Cenozoic long-term cooling trend (e.g. Zachos et al., 2008).

\section{Material and methods}

A 120 meter-long Eocene nannofossil chalk record from ODP Site 1258 (3192 m water depth) (Fig. 1) characterized by persistent cyclicity in physical property data and also with good biostratigraphic as well as magnetostratigraphic age control (Erbacher et al., 2004; Suganuma and Ogg, 2006) was analyzed in detail. We XRF scanned along the shipboard composite depth section (meters composite depth, mcd) for ODP Site 1258 from 32 to $135 \mathrm{mcd}$ (Shipboard Scientific Party, 2004a) spanning the time interval from magnetochrons $\mathrm{C} 21 \mathrm{r}$ to $\mathrm{C} 24 \mathrm{n}$ (48 to $54 \mathrm{Ma}$ ), with extensively overlapping sections at the splice tie-points in order to proof the quality of the shipboard splice. In this study we present the XRF data for this depth interval. The XRF core scanner acquires bulk-sediment chemical data from split core surfaces (Richter et al., 2006; Tjallingii et al., 2007). Although measured elemental intensities are predominantly proportional to concentration, they are also influenced by the energy level of the X-ray source, the count time, and the physical properties of the sediment (Röhl and Abrams, 2000). Fe (iron) data were collected every $2 \mathrm{~cm}$ down-core over a $1 \mathrm{~cm}^{2}$ area using a sampling time of $30 \mathrm{~s}$. We used a generator setting of $20 \mathrm{kV}$ and an X-ray current of $0.087 \mathrm{~mA}$. Measurements were made directly on the split core surface of the archive half with the first generation of XRF Core Scanners at the University of Bremen (Röhl and Abrams, 2000). The complete data set presented in this paper is available online in the WDC-MARE Pangaea database under www.pangaea.de (http://doi.pangaea.de/10.1594/PANGAEA.722915).

\section{Results}

\subsection{XRF data}

Magnetostratigraphy (Suganuma and Ogg, 2006), along with detailed spectral analysis and cyclostratigraphy of the XRF Fe intensity data (Tables S1, S2 and S3, http://www. clim-past.net/5/309/2009/cp-5-309-2009-supplement.pdf) reveal that the studied interval spans $\sim 6.5$ myr from magnetochrons C21n to C24r (Fig. 1). The record also contains the two Eocene Thermal Maxima (ETMs): Elmo (ETM2) (Lourens et al., 2005) and "X" (ETM3) (Röhl et al., 2005). Both events show very prominent peaks in Fe intensity, which is related to the global dissolution of calcium carbonate in the deep ocean during the events. Variations in $\mathrm{Fe}$ intensity are generally related to the terrigenous fraction of the sediment and/or dilution of calcium carbonate (Fig. 2).

\subsection{Composite section and refined magnetostratigraphy}

Due to both the high resolution and quality of the XRF core scanner Fe intensity data, we were able to substantially improve the shipboard composite section ("splice") for ODP Site 1258 (see Tables S4 and S5, Figs. S1 to S3, http://www.clim-past.net/5/309/2009/ cp-5-309-2009-supplement.pdf) which was mainly based on the magnetic susceptibility (MS) records and still had ambiguous correlations in several cases. Some of the ambiguity of the ship splice can be clearly identified, e.g. for the upper 50 meters (see Figs. S2A and S3A). However, neither MS nor XRF scanner data do show a good match for the parallel holes around $40 \mathrm{mcd}$ using the ship offset table. We successfully readjusted the depths at this position using new XRF scanner data. The improved correlation result into a composite section which is now $4 \mathrm{~m}$ shorter than the shipboard splice at $40 \mathrm{rmcd}$. The results also reveal that the MS data for Holes 1258A and 1258B differ substantially. Another example at $62 \mathrm{mcd}$ demonstrates that MS data clearly mismatch between holes. In fact, XRF scanner data show that the bottom of Core 1258B-6R and the top of Core 1258B$7 \mathrm{R}$ overlap by a few decimeter. We are confident that these examples clearly demonstrate that XRF scanner data were essential in revising the splice for Site 1258. The revised splice is about 6 meters shorter than the shipboard splice. Applying the average sedimentation rate of $1.5 \mathrm{~cm} / \mathrm{kyr}$ for the middle Eocene to late Paleocene (Shipboard Scientific Party, 2004a) this difference represents roughly $400 \mathrm{kyr}$. This clearly demonstrates the importance of XRF data for obtaining complete stratigraphic records, which are necessary for a precise cyclostratigraphy (also see Röhl et al., 2007; Westerhold et al., 2007, 2008). The new composite section also 

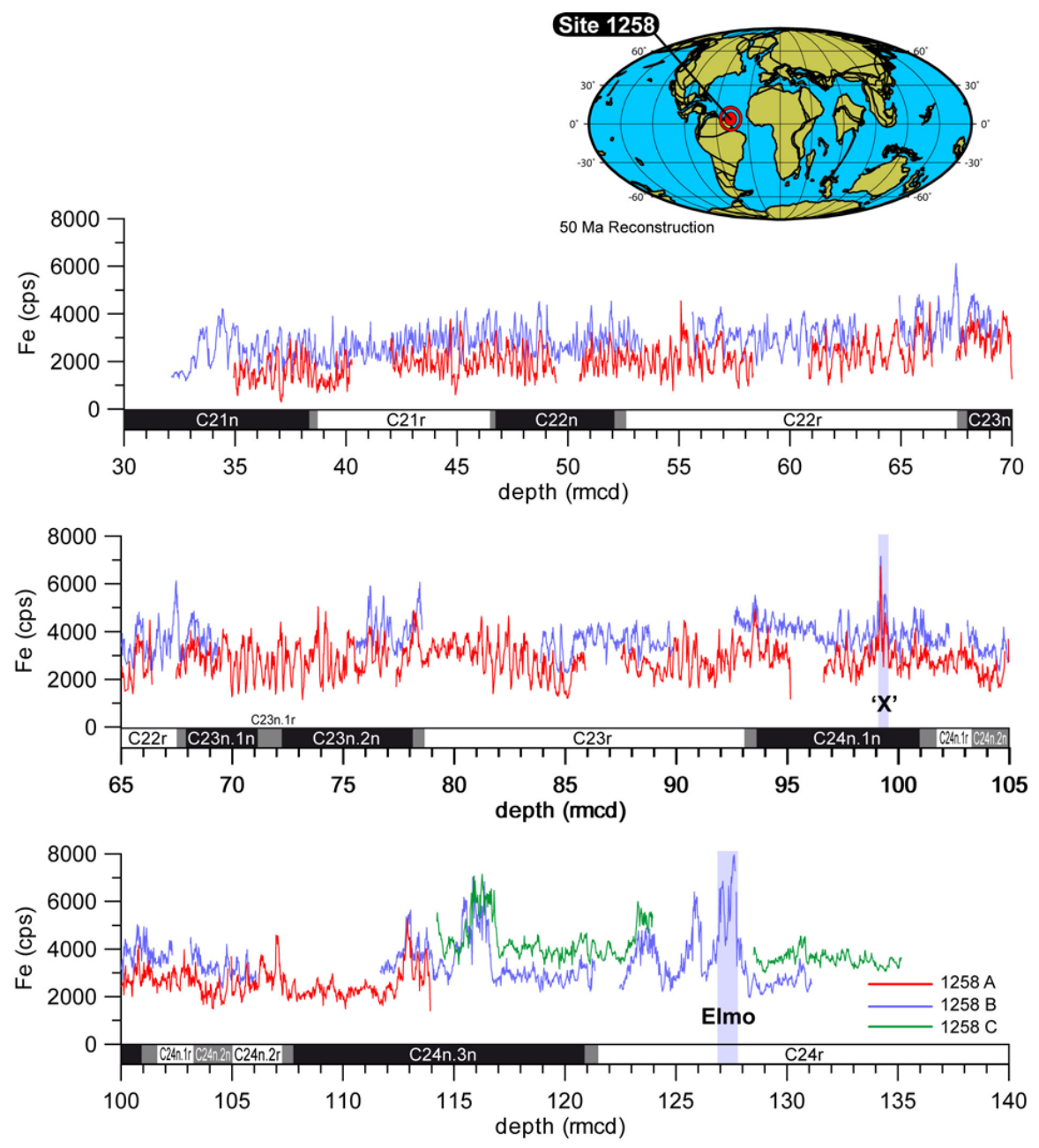

Fig. 1. XRF Fe intensity records from ODP Site 1258 plotted against revised meters composite depth (rmcd) and the early Eocene (50.0 Ma) paleogeographic reconstruction showing the location of the drill site. Reconstruction made using the Web-based software at http://www. odsn.de/odsn/services/paleomap/paleomap.html, (Hay, 1999). XRF intensity data from the A-hole in red, from the B-hole in blue and from the C-hole in green. Data from the B-hole and C-hole have been offset for clarity by 1000 and 2000 counts per second (cps), respectively. The position of magnetochron boundaries with error ranges are plotted in gray bars. The two light gray lines mark the position of the ETM2 (Elmo) and ETM3 ("X" event).

provides new composite depths for polarity zone boundaries at ODP Site 1258 (Fig. 3 and Table S6, http://www.clim-past. net/5/309/2009/cp-5-309-2009-supplement.pdf).

The magnetostratigraphic interpretation relies on shorebased discrete sampling as the shipboard magnetometer measurements where generally compromised by weak magnetizations (Suganuma and Ogg, 2006). The reversal pattern is well resolved but there is inconsistency in the interpretation of the polarity pattern between Holes 1258A and 1258B after adjustment to mcd between lower Chron $23 \mathrm{n}(\sim 100 \mathrm{mcd})$ and C22n ( $\sim 50 \mathrm{mcd}$ ) (Suganuma and Ogg, 2006) (Fig. 3). The interpretation of Suganuma and Ogg (2006) resulted from the comparison of sedimentary features based on magnetic susceptibility data and biostratigraphic datums. In particular, the offset of foraminifer Zone P8/P7 near the top of the "distorted" C23n was interpreted to result from a possible unrecognized fault in Hole 1258A which might have truncated the uppermost part of $\mathrm{C} 23 \mathrm{n}$ in Hole $1258 \mathrm{~B}$ and/or truncated the overlying Chron 22r in Hole 1258A. In addition they interpreted the occurrence of Orthorhabdus tribrachiatus in Cores 1258B-7R and -8R to be reworked as examples of these species were found well above the datum for the base of planktonic foraminifer Zone P9 (Shipboard Scientific Party, 2004a). Following this interpretation the normal polarity interval at $80 \mathrm{mcd}$ (Fig. 3b) at each site has been flagged as a pervasive overprint because it lies between $\mathrm{C} 22 \mathrm{n}$ and C23n (see also Fig. F5 in Suganuma and Ogg, 2006). These anomalous normal polarities lead Suganuma and Ogg (2006) 


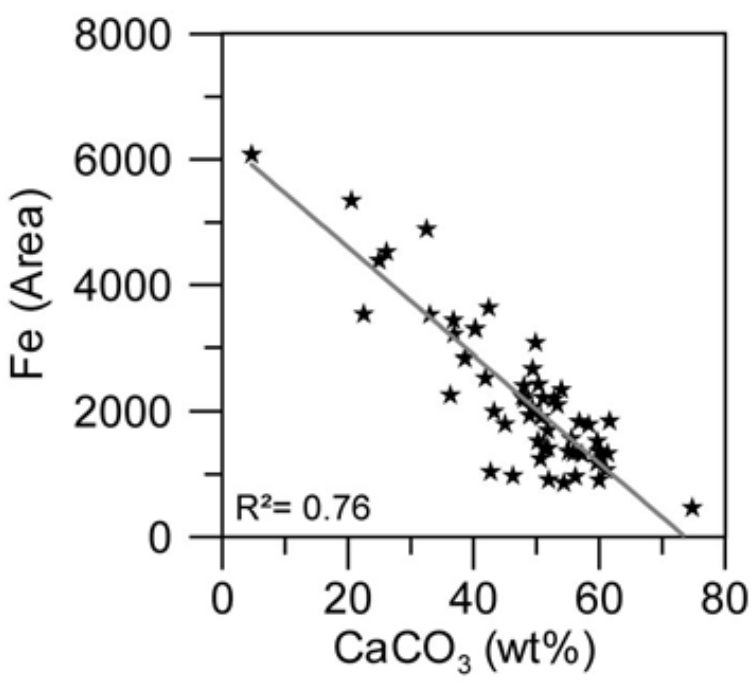

Fig. 2. Plot of XRF Fe intensity data versus shipboard $\mathrm{CaCO}_{3}$ (wt $\%$ ) measured on the same sample position. The negative linear regression line shows an anti-correlation between the amount of $\mathrm{CaCO}_{3}$ and $\mathrm{XRF}$ Fe intensity at ODP Site 1258, suggesting that the $\mathrm{Fe}$ (cps) is related to the amount of terrigenous component in the sediment.

to the conclusion that either the upper part of the section was not effectively demagnetized or a hypothetical fault duplicated some portion of the record. This interpretation of Suganuma and Ogg (2006) now definitely needs revision as updated nannofossil datums are available (Fig. 3). We are confident that the recalibrated nannofossil events of Agnini et al. (2006) and Agnini et al. (2007) are much more reliable than the planktonic foraminifera zonation of Berggren et al. (1995). According to Agnini et al. (2006) the LO (Lowest Occurrence) of N. fulgens is in the middle part of magnetochron $\mathrm{C} 21 \mathrm{n}$, the $\mathrm{HO}$ (Highest Occurrence) of D. lodoensis is within $\mathrm{C} 21 \mathrm{r}$, and the $\mathrm{HO}$ of $\mathrm{T}$. orthostylus is close to the base of 22r. The LO of D. lodoensis is close to the top of C24n (Agnini et al. 2006), the LO of S. radians is in the lower portion of C24n (Agnini et al., 2006), and the LO of T. orthostylus is close to the top of C24r (Agnini et al., 2007). Based on this data the normal chron described as a pervasive overprint (Suganuma and Ogg, 2006) from 68 to $78 \mathrm{rmcd}$ must be instead C23n. The normal polarity from $\sim 100$ to $\sim 128 \mathrm{rmcd}$ would be assigned to $\mathrm{C} 24 \mathrm{n}$. This then leads to the interpretation as used in this study (Table S6). The excellent matching of XRF scanner Fe data which refined the splice clearly does not allow moving cores to align the reversal boundary at $\sim 84 \mathrm{rmcd}$ in Hole $1258 \mathrm{~A}$ with the boundary at $\sim 94$ rmcd. In addition the sediment color changes from red to gray at $\sim 84 \mathrm{rmcd}$ in Hole $1258 \mathrm{~A}$ indicates geochemical changes. We therefore define the reversal boundary at $\sim 94 \mathrm{rmcd}$ in Hole 1258B in accordance with the nannofossil datum positions as the top of $\mathrm{C} 24 \mathrm{n}$.

\section{Cyclostratigraphy}

Parallel bands in the evolutionary Wavelet Power Spectra of the Fe intensity data of ODP Site 1258 demonstrate that spectral power is located at distinct periods (Fig. S4) (Wavelet software was provided by C. Torrence and G. Compo http: //paos.colorado.edu/research/wavelets). Multi-Taper Method (MTM) spectra were calculated by the kSpectra Toolkit software from SpectraWorks using 3 tapers and a resolution of 2 (Ghil et al., 2002). Background estimate and hence confidence levels are based on a robust red noise estimation (Mann and Lees, 1996). Bio- and magnetostratigraphic data as well as diagnostic frequency ratios clearly relate these bands to Milankovitch cycles. We could identify all long (405-kyr) and short (100-kyr) eccentricity, obliquity, and precession components. In order to extract the long and short eccentricity cycles from the sedimentary records we followed the approach of Weedon $(1993,2003)$ : prior to wavelet analysis the data were detrended and normalized; counting of the eccentricity, obliquity and precession cycles resulted in revised estimates for the durations of magnetochrons $\mathrm{C} 21 \mathrm{r}$ through C24n (Figs. 4 and 5). Due to lowered sedimentation rates above the $\mathrm{C} 22 \mathrm{r} / \mathrm{C} 23 \mathrm{n}$ boundary the clear recognition of precession cycles at ODP Site 1258 is restricted and precession cycle counting in the interval from $\mathrm{C} 21 \mathrm{r}$ to $\mathrm{C} 22 \mathrm{r}$ is not possible at all. Nevertheless, both the short and the stable long eccentricity cycle can still be extracted. We used both direct cycle counting and Gaussian band pass filtering of the data to construct a cyclostratigraphy from the base of $\mathrm{C} 21 \mathrm{r}$ down to the base of C24n (Figs. 4 and 5).

Due to the still existing discrepancy between astronomical solutions and radiometric dating in the late Paleocene and early Eocene in combination with the lack of absolute ages as suitable reference points (Westerhold et al., 2007), a naming scheme as proposed by Wade and Pälike (2004) for their Oligocene record cannot be applied for the Eocene right now. However, we follow a similar approach and propose an Eocene stratigraphic nomenclature related to the recognition of short and long eccentricity cycles. The cycle count number is defined by the identified maxima in the Fe data corresponding to an eccentricity cycle maximum (see Figs. 3 and 4). The stable long eccentricity cycles are referred to as $\mathrm{Ec}_{405} 1, \mathrm{Ec}_{405} 2, \ldots, \mathrm{Ec}_{405} 21$ (Ec for Eocene) upwards. The short eccentricity cycles are referred to as $\mathrm{Ec}_{100} 1, \mathrm{Ec}_{100} 2$, ..., $\mathrm{Ec}_{100} 85$ upwards. We start counting at the Eocene Thermal Maximum 2 (ETM2, Lourens et al., 2005) which is located in precession cycle 88, the middle of $\mathrm{Ec}_{100} 19$ and before the maximum of the $\mathrm{Ec}_{405} 5$ cycle (Westerhold et al., 2007).

\subsection{Chron C24n}

We counted $60 \pm 2 \frac{1}{2}$ precession cycles (precession cycles 101 to 161 ) and $13^{1} / 4^{1} / 2$ short eccentricity cycles $\left(\mathrm{Ec}_{100} 22\right.$ to $\left.\mathrm{Ec}_{100} 35\right)$ for $\mathrm{C} 24 \mathrm{n}$ (Fig. 4a, Table 1). Wavelet 

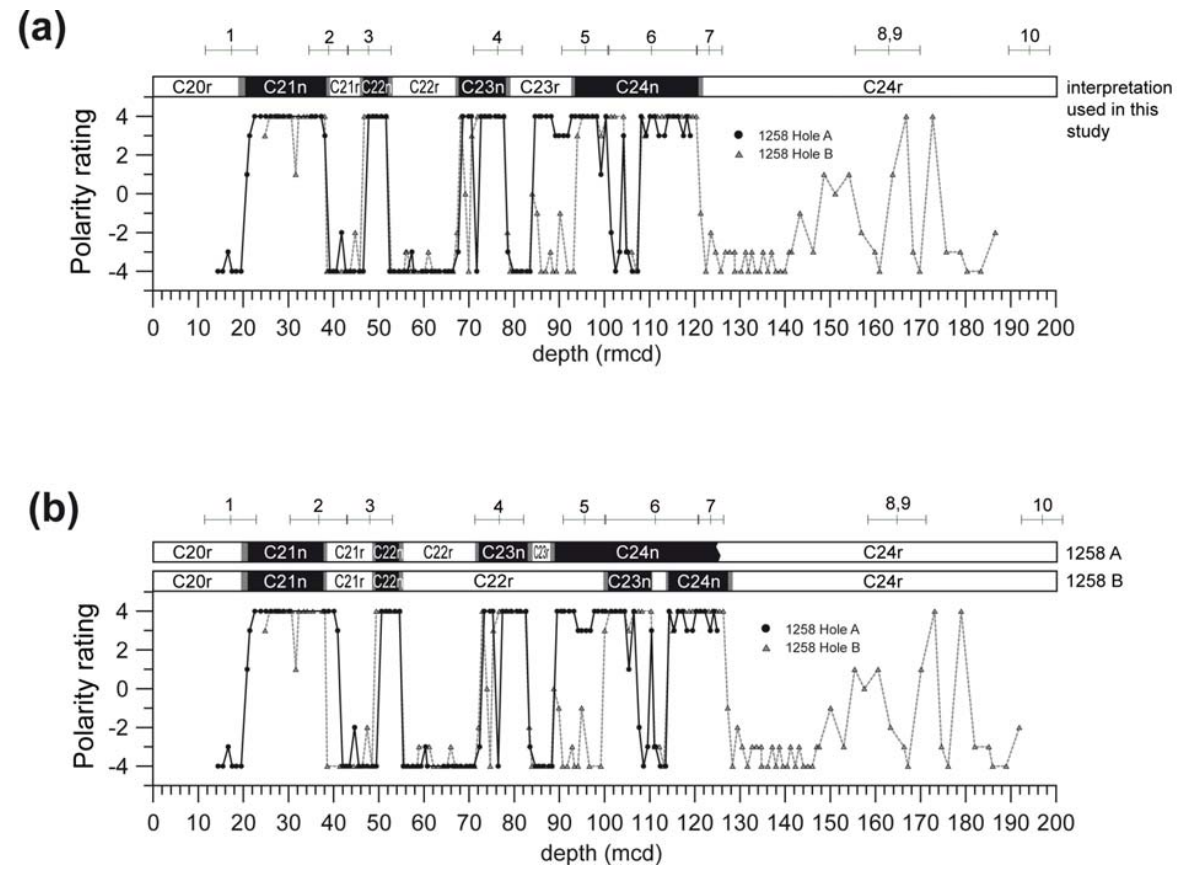

Fig. 3. Polarity rating scheme of the inclination data from ODP Holes 1258A (triangles) and B (dots) (Suganuma and Ogg, 2006) with the paleomagnetic reversal pattern interpretation of this study (a) and the original interpretation (b) of Suganuma and Ogg (2006). Please note that (a) is plotted on the revised composite depth (rmcd) skale and (b) is plotted against the shipboard composite depth (mcd). The magnetostratigraphy of ODP Site 1258 in relation to the revised composite depth (rmcd) is given in Table S6. For details of the polarity rating scheme see Suganuma and Ogg (2006). Legends for nannofossil datums from Hole 1258A (Shipboard Scientific Party 2004a): 1 LO N. fulgens, $2 \mathrm{HO}$ D. sublodoensis, $3 \mathrm{HO}$ D. lodoensis, $4 \mathrm{HO}$ T. orthostylus, 5 LO D. lodoensis, 6 LO S. radians, 7 LO T. orthostylus, 8 LO D. diastypus, $9 \mathrm{HO}$ D. multiradiatus, $10 \mathrm{HO}$ Fasciculitus spp..

analysis (Fig. S5a) indicates that this interval is characterized by precession cycles strongly modulated by eccentricity but with a significant obliquity component in the lower part. A change in amplitude and cycle thickness from thicker to thinner cycles occurs around $112 \mathrm{rmcd}$ (revised meters composite depth) between $\mathrm{Ec}_{100} 25$ and $\mathrm{Ec}_{100} 26$ in the middle of magnetochron $\mathrm{C} 24 \mathrm{n} .3 \mathrm{n}$. In addition, the prominent " $\mathrm{X}$ " event (ETM3, Röhl et al., 2005, 2009) is represented by precession cycles 146 and 147, and lies in the middle of $\mathrm{Ec}_{100} 32$, and in the middle of $\mathrm{Ec}_{405} 8$.

If we use $21 \mathrm{kyr}$ and $95 \mathrm{kyr}$ as the mean durations for the counted precession and short eccentricity cycles (Herbert et al., 1995), the duration of C $24 \mathrm{n}$ is estimated as $1260 \pm 53 \mathrm{kyr}$ and $1259 \pm 48 \mathrm{kyr}$, respectively. This is more than $100 \mathrm{kyr}$ longer than the GPTS2004 estimate and $277 \mathrm{kyr}$ longer than the Cande and Kent (1995) estimate, but close to the cyclostratigraphy of ODP Site 1051 (Röhl et al., 2003). The base of $\mathrm{C} 24 \mathrm{n} .1 \mathrm{n}$ lies in $\mathrm{Ec}_{100} 31$ and the top in $\mathrm{Ec}_{100} 35$. The paleomagnetic interpretation of C24n.2n at ODP Site 1258 is weak and thus the proposed duration of 84 to $90 \mathrm{kyr}$ is uncertain. The base of $\mathrm{C} 24 \mathrm{n} .3 \mathrm{n}$ is in $\mathrm{Ec}_{100} 22$ and the top is between $\mathrm{Ec}_{100} 27$ and $\mathrm{Ec}_{100} 28$.

\subsection{Chron C23n and C23r}

C23n equals $32^{1} / 2 \pm 3$ precession cycles (precession cycles 200 to 232$)$ and $7 \frac{1}{2} \pm^{1} / 2$ short eccentricity cycles $\left(\mathrm{Ec}_{100} 44\right.$ to $\mathrm{Ec}_{100} 51$ ) (Fig. 4b, Table 1). For C23r (Fig. 4b, Table 1) we counted $38 \pm 3$ precession cycles (precession cycles 161 to 199$)$ and $8 \frac{3}{4} \pm^{3} / 4$ short eccentricity cycles $\left(\mathrm{Ec}_{100} 36\right.$ to $\left.\mathrm{Ec}_{100} 44\right)$. Wavelet analysis shows that the strong precession component apparent with a period of $42 \mathrm{~cm}$ during the entire magnetochron C24n continues upward to a depth of $80 \mathrm{rmcd}$ (Fig. S5b). A small change in cycle thickness from thicker to thinner cycles appears around $80 \mathrm{rmcd}$ between $\mathrm{Ec}_{100} 42$ and $\mathrm{Ec}_{100} 43$ close to the top of magnetochron $\mathrm{C} 23 \mathrm{r}$. A very interesting feature is the rather low amplitude of the eccentricity component in cycle $\mathrm{Ec}_{405} 10$ (Fig. 3b). This interval probably represents the sedimentary expression of a minimum in the very long eccentricity cycle $(\sim 2.4 \mathrm{myr})$ covering the period from $\mathrm{Ec}_{100} 39$ to $\mathrm{Ec}_{100} 43$. The precession component is well documented in magnetochron C23n. Because of the lowered sedimentation rate some short eccentricity cycles $\left(\mathrm{E}_{100} 44\right.$, $\mathrm{E}_{100} 51, \mathrm{E}_{100} 50$ ) are clearly visible while precession cycles are suppressed. Cycle counting suggests that the duration of magnetochron $\mathrm{C} 23 \mathrm{r}$ is $798 \pm 63 \mathrm{kyr}$ using precession cycles and $831 \pm 72$ kyr using short eccentricity cycles. For C23n we 

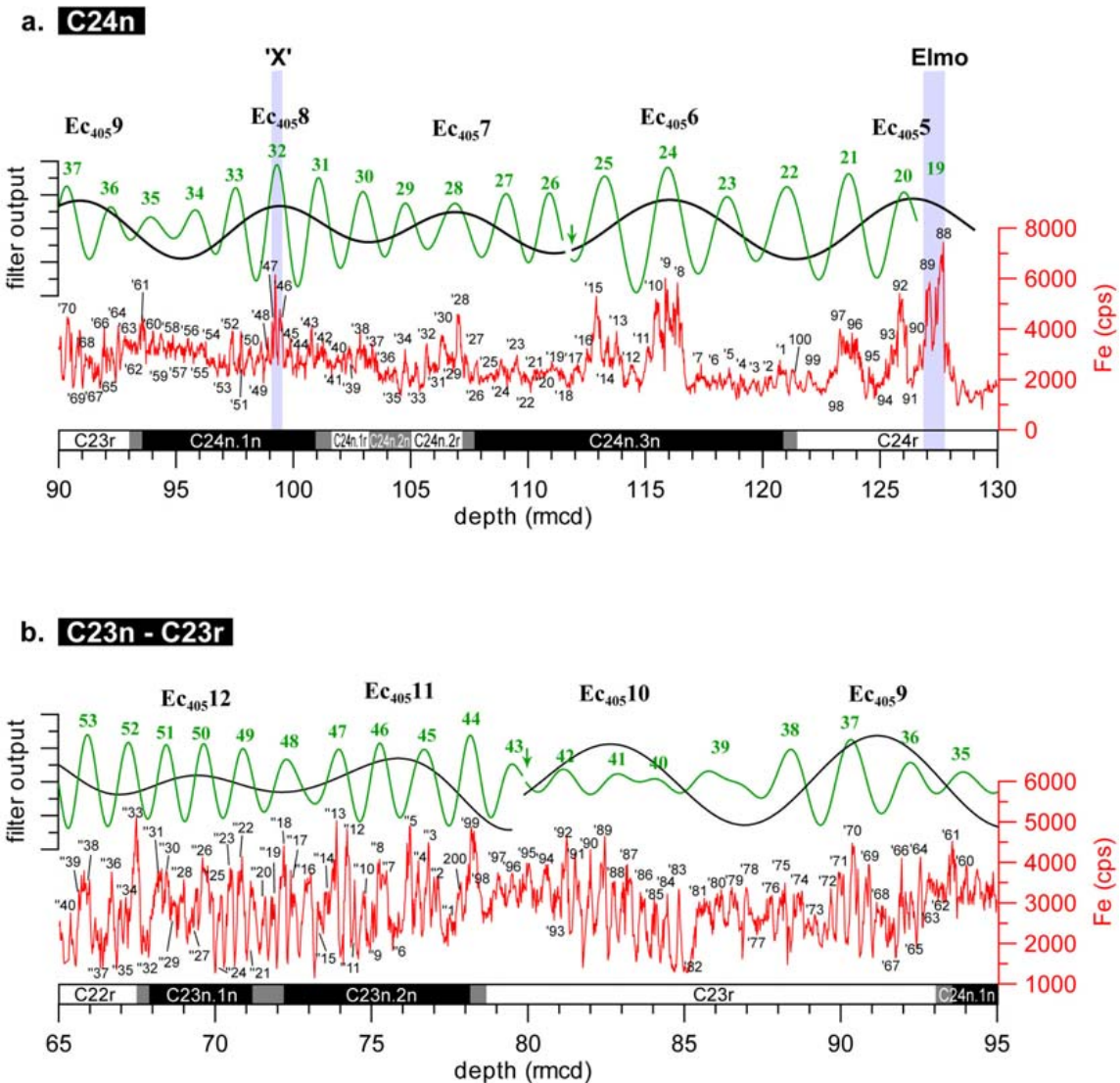

Fig. 4. High-resolution XRF Fe intensity data and cyclostratigraphy across magnetochrons $\mathrm{C} 24 \mathrm{n}$ (a) and $\mathrm{C} 23$ (b) (Ec 4055 to $\left.\mathrm{Ec}_{405} 12\right)$ for sediments from ODP Site 1258. The positions of the ETM2 (Elmo) and ETM3 ("X" event) are indicated (blue bars). The short (green) and long (thick black) eccentricity-related cycles have been extracted by Gaussian filtering. The filters have been adjusted according to the proposed change in cycle thickness by detailed wavelet analysis (for details see supplementary Fig. S3, http://www.clim-past.net/5/309/2009/ cp-5-309-2009-supplement.pdf). Green arrows indicate changes in the width of the applied bandpass filter. Gray numbers indicate the short eccentricity $\left(\mathrm{Ec}_{100}\right)$ maxima and the black labels indicate the long eccentricity $\left(\mathrm{Ec}_{405}\right)$ maxima relative to the P/E boundary. For further discussion see text. For MTM spectra see Fig. 6. (Filter details: a, 112 to $127 \mathrm{rmcd} 405-\mathrm{kyr}$ filter at $0.11 \pm 0.03 \mathrm{cycle} / \mathrm{meter}$ (c/m) and $100-\mathrm{kyr}$ filter at $0.39 \pm 0.12 \mathrm{c} / \mathrm{m}$. 90 to $112 \mathrm{rmcd} 405-\mathrm{kyr}$ filter at $0.12 \pm 0.03 \mathrm{c} / \mathrm{m}$ and $100-\mathrm{kyr}$ filter at $0.54 \pm 0.16 \mathrm{c} / \mathrm{m}$. b, 80 to $95 \mathrm{rmcd} 405-\mathrm{kyr}$ filter at $0.12 \pm 0.03 \mathrm{c} / \mathrm{m}$ and $100-\mathrm{kyr}$ filter at $0.54 \pm 0.16 \mathrm{c} / \mathrm{m}$. 65 to $95 \mathrm{rmcd} 405-\mathrm{kyr}$ filter at $0.16 \pm 0.05 \mathrm{c} / \mathrm{m}$ and $100-\mathrm{kyr}$ filter at $0.75 \pm 0.22 \mathrm{c} / \mathrm{m}$.)

calculated a duration of $683 \pm 63 \mathrm{kyr}$ and $713 \pm 48 \mathrm{kyr}$, respectively (Table 1). It is interesting to note that $\mathrm{C} 23 \mathrm{n} .2 \mathrm{n}$ is much shorter and $\mathrm{C} 23 \mathrm{r}$ is a little bit longer according to our results than in CK95 and GPTS2004. The base of C23n.1n lies in $\mathrm{Ec}_{100} 49$ and the top lies between $\mathrm{Ec}_{100} 51$ and $\mathrm{Ec}_{100} 52$. The base of $\mathrm{C} 23 \mathrm{n} .2 \mathrm{n}$ lies in $\mathrm{Ec}_{100} 44$ and the top lies in $\mathrm{Ec}_{100} 48$. In summary, the duration of magnetochron $\mathrm{C} 23$ as defined at ODP Site 1258 is $1481 \pm 63 \mathrm{kyr}$ based on precession cycle counting. This would be $100 \mathrm{kyr}$ less than in CK95 and $400 \mathrm{kyr}$ less than in GPTS2004.

\subsection{Chron C22n and C22r}

The relatively low sedimentation rate of these magnetochrons at Site 1258 does not allow clear identification of precession cycles from $67 \mathrm{rmcd}$ to the top of the investigated interval. However, C22n equals $6 \pm^{3} / 4$ short eccentricity cycles $\left(\mathrm{Ec}_{100} 66\right.$ to $\left.\mathrm{Ec}_{100} 72\right)$ (Fig. 5a, Table 1). We counted $14 \% 4 \pm 1$ short eccentricity cycles $\left(\mathrm{Ec}_{100} 52\right.$ to $\left.\mathrm{Ec}_{100} 66\right)$ for magnetochron C22r (Fig. 5a, Table 1). Wavelet analysis demonstrates that from 65 to $55 \mathrm{rmcd}$ the eccentricity component with a period of $125-133 \mathrm{~cm}$ (Fig. S4c) is replaced by a strong cycle with a $46-\mathrm{cm}$ period. These $\sim 46-\mathrm{cm}$ cycles diminish in power after $55 \mathrm{rmcd}$ and shift towards a thickness of $40 \mathrm{~cm}$. Much stronger eccentricity cycles are found from 55 to $45 \mathrm{rmcd}$. A decrease in sedimentation rates is documented by the decrease of the short eccentricity cycle period from $125 \mathrm{~cm} /$ cycle in the interval 65 to $70 \mathrm{rmcd}$ to $97 \mathrm{~cm} /$ cycle from 55 to $45 \mathrm{rmcd}$. On the basis of the overall Milankovitch cycle relationship and assuming a smooth rather than rapid shift in the sedimentation rate within the interval from 70 to $45 \mathrm{rmcd}$ as well as a persistent main 
Table 1. Duration of magnetochrons derived from cyclostratigraphy based on XRF Core Scanner data.

\begin{tabular}{|c|c|c|c|c|c|c|c|}
\hline \multirow[t]{3}{*}{ Chron } & \multicolumn{2}{|c|}{ standard GPTS } & \multirow{3}{*}{$\begin{array}{c}\text { tuning }^{\dagger} \\
(\mathrm{kyr})\end{array}$} & \multicolumn{4}{|c|}{ cycle counting } \\
\hline & \multirow{2}{*}{$\begin{array}{l}\text { CK95 } \\
(\mathrm{kyr})\end{array}$} & \multirow{2}{*}{$\begin{array}{l}\text { GPTS2004 } \\
(\mathrm{kyr})\end{array}$} & & \multicolumn{2}{|c|}{ Precession } & \multicolumn{2}{|c|}{ short Eccentricity } \\
\hline & & & & no. of cycles & $(\mathrm{kyr})^{\ddagger}$ & no. of cycles & $(\mathrm{kyr})^{\#}$ \\
\hline $\mathrm{C} 21 \mathrm{r}$ & 1131 & 1364 & $1265 \pm 40$ & & & $13 \pm \frac{1}{2}$ & $1235 \pm 48$ \\
\hline $\mathrm{C} 22 \mathrm{n}$ & 677 & 828 & $638 \pm 58$ & & & $6 \pm \frac{3}{4}$ & $570 \pm 72$ \\
\hline $\mathrm{C} 22 \mathrm{r}$ & 1064 & 1303 & $1469 \pm 63$ & & & $14 \frac{3}{4} \pm 1$ & $1401 \pm 95$ \\
\hline $\mathrm{C} 23 \mathrm{n}$ & 965 & 1171 & $675 \pm 45$ & $32 \frac{1}{2} \pm 3$ & $683 \pm 63$ & $7 \frac{1}{2} \pm \frac{1}{2}$ & $713 \pm 48$ \\
\hline C23n.1n & 168 & 202 & $224 \pm 61$ & $10 \frac{3}{4} \pm 3 \frac{1}{4}$ & $226 \pm 68$ & $2 \frac{3}{4} \pm 1$ & $261 \pm 95$ \\
\hline C23n.1r & 101 & 125 & $72 \pm 53$ & $3 \frac{1}{2} \pm 2 \frac{1}{2}$ & $74 \pm 53$ & $1 \pm 1$ & $95 \pm 95$ \\
\hline $\mathrm{C} 23 \mathrm{n} .2 \mathrm{n}$ & 696 & 844 & $379 \pm 55$ & $19 \pm 3$ & $399 \pm 63$ & $4 \pm 1$ & $380 \pm 95$ \\
\hline $\mathrm{C} 23 \mathrm{r}$ & 621 & 747 & $800 \pm 46$ & $38 \pm 3$ & $798 \pm 63$ & $8 \frac{3}{4} \pm \frac{3}{4}$ & $831 \pm 72$ \\
\hline $\mathrm{C} 24 \mathrm{n}$ & 983 & 1159 & $1299 \pm 42$ & $60 \pm 2 \frac{1}{2}$ & $1260 \pm 53$ & $13 \frac{1}{4} \pm \frac{1}{2}$ & $125 \pm 48$ \\
\hline C24n.1n & 299 & 355 & $390 \pm 52$ & $18 \frac{1}{2} \pm 1 \frac{1}{2}$ & $389 \pm 63$ & $4 \pm \frac{1}{2}$ & $380 \pm 48$ \\
\hline C24n.1r & 94 & 112 & 125 & $5 \pm 1 \frac{1}{2}$ & $105 \pm 32$ & $1 \frac{1}{4}$ & 119 \\
\hline$C 24 n .2 n$ & 44 & 52 & 75 & 4 & 84 & 1 & 95 \\
\hline $\mathrm{C} 24 \mathrm{n} .2 \mathrm{r}$ & 102 & 119 & 142 & $7 \pm 1$ & $147 \pm 21$ & $1 \frac{1}{4}$ & 119 \\
\hline C24n.3n & 444 & 521 & $567 \pm 37$ & $25 \pm 2$ & $525 \pm 42$ & $5 \frac{1}{2} \pm \frac{1}{2}$ & $523 \pm 48$ \\
\hline
\end{tabular}

$\dagger$ tuned to the stable 405-kyr long eccentricity cycle

$\ddagger$ assuming $21 \mathrm{kyr}$ for each precession cycle

\# assuming $95 \mathrm{kyr}$ for each short eccentricity cycle

Note: error given only takes uncertainty in cycle counting in account; the error does not include the uncertainty in paleomagnetic interpretation.

thickness of the short eccentricity cycle of around 97 to $125 \mathrm{~cm}$, we interprete that the observed strong 46-cm cyclicity is obliquity related. We extracted the obliquity component and counted 19 cycles from $\sim 65.6$ to $\sim 55.0 \mathrm{rmcd}$ (Fig. 5). For the same interval we were able to extract 8 relatively weak eccentricity cycles. Applying average durations of $41 \mathrm{kyr}$ for an obliquity cycle and $95 \mathrm{kyr}$ for a short eccentricity cycle (Herbert et al., 1995) the interval would span $779 \mathrm{kyr}$ or $760 \mathrm{kyr}$, respectively. This exceptionally strong and unique obliquity component could be related to a minimum in the very long eccentricity cycle covering the period from $\mathrm{Ec}_{100} 55$ to $\mathrm{Ec}_{100} 62$ and will be discussed below.

Cycle counting suggests that the duration of $\mathrm{C} 22 \mathrm{r}$ is $1401 \pm 95$ kyr using short eccentricity cycles. For C22n we calculated a duration of $570 \pm 72 \mathrm{kyr}$ (Table 1). The base of $\mathrm{C} 22 \mathrm{n}$ is in $\mathrm{Ec}_{100} 66$ and the top is at the base of $\mathrm{Ec}_{100} 72$. The base of $\mathrm{C} 22 \mathrm{r}$ is in $\mathrm{Ec}_{100} 52$ and the top is in $\mathrm{Ec}_{100} 72$. The total duration of magnetochron C22 is $1923 \pm 95 \mathrm{kyr}, 182 \mathrm{kyr}$ longer than in CK95 and $208 \mathrm{kyr}$ shorter than in GPTS2004.

\subsection{Chron C21r}

We counted $13 \pm \frac{1}{2}$ short eccentricity cycles $\left(\mathrm{Ec}_{100} 72\right.$ to $\mathrm{Ec}_{100} 85$ ) for C21r (Fig. 5b, Table 1) where the Eocene composite record ends at this site (Shipboard Scientific Party, 2004a). Wavelet analysis shows a shift in short eccentricity cycle thickness from thicker $(97 \mathrm{~cm})$ to thinner $(58 \mathrm{~cm})$ at around $45 \mathrm{rmcd}$. The obliquity component $(39-\mathrm{cm}$ and 20 $\mathrm{cm}$ cycles, respectively; Fig. S4d) is apparent throughout the entire $\mathrm{C} 21 \mathrm{r}$ interval. According to cycle counting the duration of C21r is $1235 \pm 48 \mathrm{kyr}$ using short eccentricity cycles. This is $104 \mathrm{kyr}$ longer than in CK95 and $129 \mathrm{kyr}$ shorter than in GPTS2004. The base of C21r is at the base of $\mathrm{Ec}_{100} 72$ and the top is in $\mathrm{Ec}_{100} 85$.

\subsection{Orbital calibration to the stable long eccentricity cycle}

The precision of the orbital solution for the time interval older than $42 \mathrm{Ma}$ is limited (Laskar et al., 2004; Machlus et al., 2004; Westerhold et al., 2007). Therefore, a definite tuning of the early Eocene record of ODP Site 1258 to orbital solutions is not possible at this stage. However, orbital tuning should be feasible using the long eccentricity cycle, because of its stability far back in time (Laskar et al., 2004; Varadi et al., 2003), resulting in a still floating time scale (i.e. Hinnov and Ogg, 2007). We tuned the ODP Site $1258 \mathrm{Fe}$ record by assigning the extracted long eccentricity related maxima to maxima in a cosine function with a period of 405-kyr (see Laskar et al., 2004; namely formula (47) therein). Arbitrarily, we set the maxima in the $\mathrm{Ec}_{405} 21$ cycle to $1 \mathrm{Ma}$ as a reference point for this relative 
a. C22n - C22r

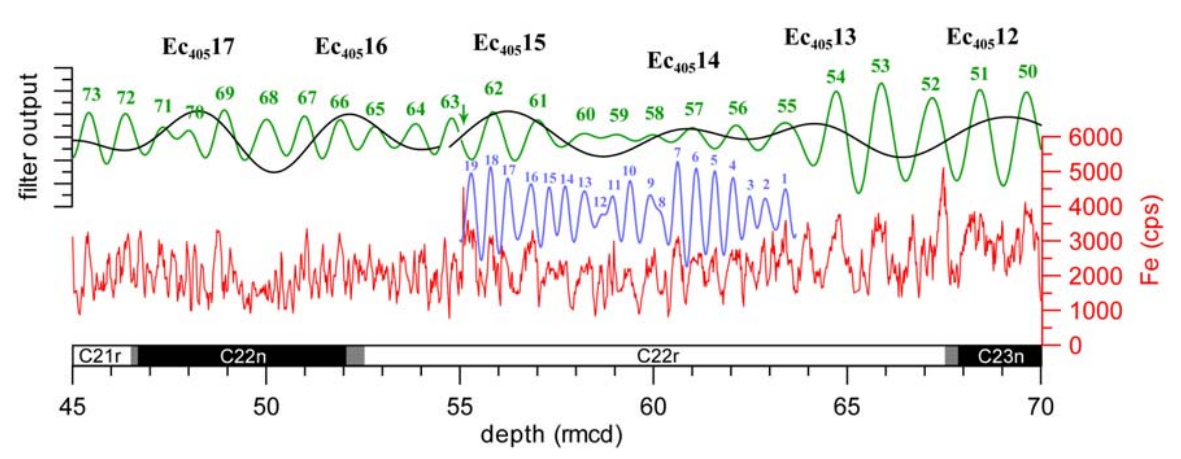

b. C21r

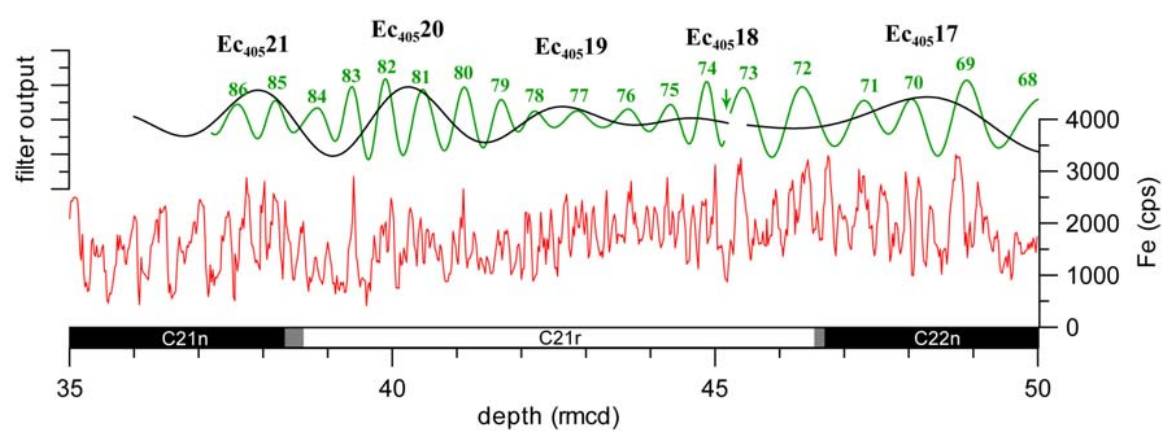

Fig. 5. High-resolution XRF Fe intensity and cyclostratigraphy across magnetochrons $\mathrm{C} 22$ (a) and $\mathrm{C} 21 \mathrm{r}$ (b) (Ec 40512 to $\left.\mathrm{Ec}_{405} 21\right)$ for sediments from ODP Site 1258. The short (green) and long (thick black) eccentricity-related cycles and obliquity-related (blue) cycles have been extracted by Gaussian filtering. The filters have been adjusted according to the proposed change in cycle thickness by detailed wavelet analysis (for details see supplementary Fig. S3, http://www.clim-past.net/5/309/2009/cp-5-309-2009-supplement.pdf). Gray arrows indicate changes in the width of the applied bandpass filter. For legend of figure see caption of Fig. 4, for discussion see text. For MTM spectra see Fig. 6. (Filter details: a, 55 to $70 \mathrm{rmcd} 405-\mathrm{kyr}$ filter at $0.22 \pm 0.06 \mathrm{cycle} / \mathrm{meter}(\mathrm{c} / \mathrm{m}), 100-\mathrm{kyr}$ filter at $0.80 \pm 0.24 \mathrm{c} / \mathrm{m}$. 90 and $41-\mathrm{kyr}$ filter at $2.18 \pm 0.65 \mathrm{c} / \mathrm{m}$. 45 to $55 \mathrm{rmcd} 405-\mathrm{kyr}$ filter at $0.25 \pm 0.07 \mathrm{c} / \mathrm{m}$ and $100-\mathrm{kyr}$ filter at $1.03 \pm 0.32 \mathrm{c} / \mathrm{m}$. b, 45 to $55 \mathrm{rmcd} 405-\mathrm{kyr}$ filter at $0.25 \pm 0.07 \mathrm{c} / \mathrm{m}$ and $100-\mathrm{kyr}$ filter at $1.03 \pm 0.32 \mathrm{c} / \mathrm{m}$. 37 to $45 \mathrm{rmcd} 405-\mathrm{kyr}$ filter at $0.43 \pm 0.13 \mathrm{c} / \mathrm{m}$ and $100-\mathrm{kyr}$ filter at $1.72 \pm 0.52 \mathrm{c} / \mathrm{m}$.)

time scale (Table S7, http://www.clim-past.net/5/309/2009/ cp-5-309-2009-supplement.pdf). Nevertheless, because of these given uncertainties in time scale construction in the early Eocene (Westerhold et al., 2007) we do not provide tuned absolute ages. A detailed comparison between the tuned relative and the cycle-counting age scales reveals only minor differences. The almost identical sedimentation rates document the slow decline from $\sim 2.5 \mathrm{~cm} / \mathrm{kyr}$ at $120 \mathrm{rmcd}$ to $\sim 0.75 \mathrm{~cm} / \mathrm{kyr}$ at $32 \mathrm{rmcd}$ (Fig. 7). Sedimentation rates derived from the CK95 and GPTS2004 time scales generally support this trend, although they exhibit a strong shift at $78 \mathrm{rmcd}$ depth right at the $\mathrm{C} 23 \mathrm{r} / \mathrm{C} 23 \mathrm{n}$ boundary directly linked to magnetochron $\mathrm{C} 23 \mathrm{n} .2 \mathrm{n}$. The new data suggest that the estimates for the duration of C23n.2n in both CK95 and GPTS2004 are too long.

\section{Discussion}

The major objective of this study is to provide a cyclostratigraphic framework for the Eocene interval equivalent to magnetochrons $\mathrm{C} 21 \mathrm{r}$ to $\mathrm{C} 24 \mathrm{n}$ ( $\sim 48$ to $54 \mathrm{Ma}$ ) from a highresolution record drilled at ODP Site 1258. If we assume that the Site 1258 record is complete and that the stable long eccentricity cycle was correctly identified we can estimate the durations of magnetochrons C21r through C24n. In the following we will discuss these new/revised data in relation to estimates used in previously published time scales (CK95, GPTS2004). We will also discuss the major implications of the new chronostratigraphy for this critical time interval, which includes the Early Eocene Climate Optimum (EECO, Zachos et al., 2001) with the highest global temperature recorded in the past $70 \mathrm{Ma}$, and the changeover to the Cenozoic long-term cooling trend. 
a.

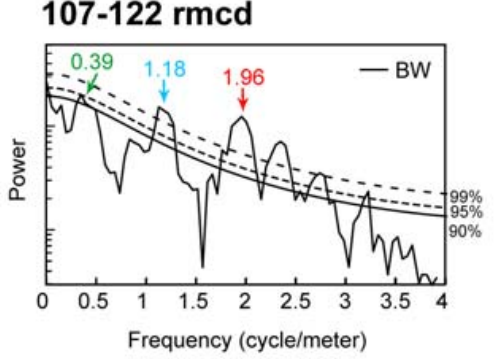

c. $\quad 78-92$ rmcd

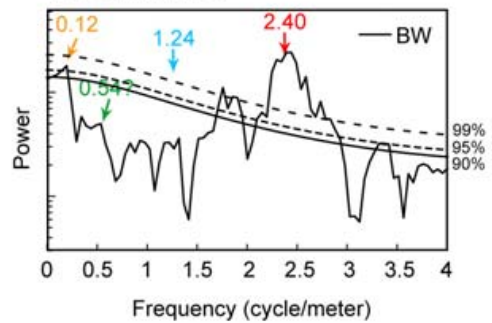

e. $\quad 65-72 \mathrm{rmcd}$

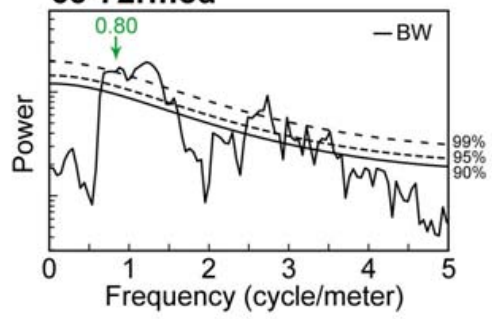

g. $\quad 45-55 \mathrm{rmcd}$

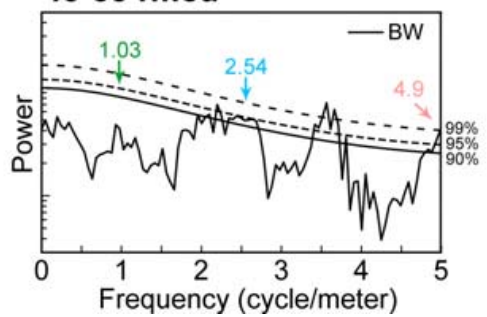

b. $\quad 89-112 \mathrm{rmcd}$

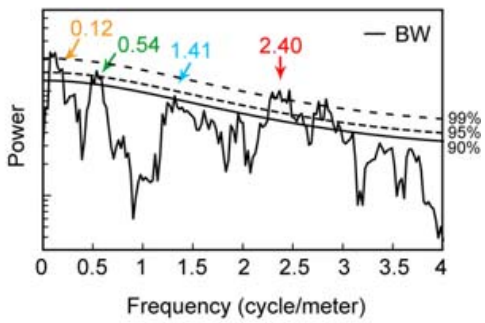

d. $\quad 66-78 \mathrm{rmcd}$

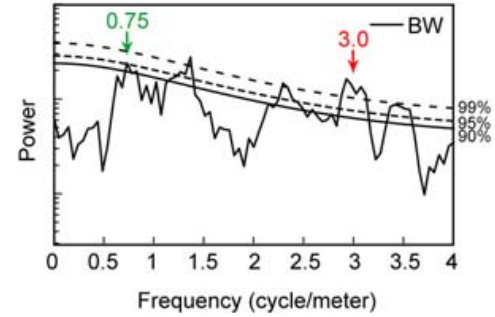

f. $\quad 55-65 \mathrm{rmcd}$

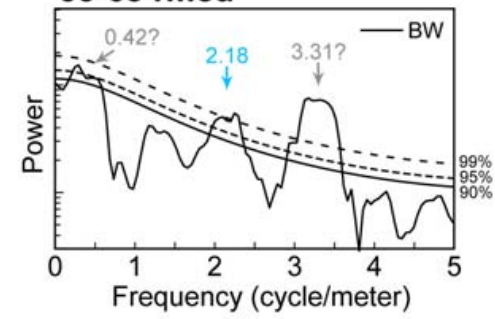

h. $\quad 37-45 \mathrm{rmcd}$

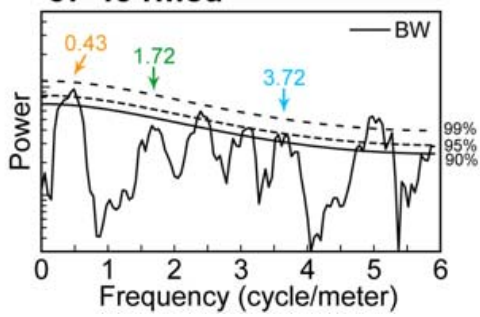

Fig. 6. MTM power spectra (bold black line) for specific depth intervals. The spectra have been calculated by the kSpectra Toolkit using 3 tapers and resolution of 2; BW indicates bandwidth. Background estimate and hence confidence levels (90\%, 95\%, 99\%) are based on a robust red noise estimation (Mann and Lees, 1996). Based on bio- and magnetostratigraphy we have identified spectral peaks that are related to the short (100-kyr; green arrows) and long (405-kyr; orange arrows) eccentricity cycles as well as obliquity (41-kyr, blue arrow) and precession (21-kyr, red arrow). MTM spectra (a) and (b) are the basis for the filter frequencies used for Fig. 4a. MTM spectra (c) and (d) are the basis for Fig. 4b filters. MTM spectra (e), (f) and (g) are the basis for Fig. 5a filters. MTM spectra g and (h) are the basis for Fig. 5b filters.

\subsection{Duration of individual magnetochrons and compar- ison to standard geomagnetic polarity time scales}

For the interval from the top of magnetochron $\mathrm{C} 21 \mathrm{r}$ to the onset of the Paleocene-Eocene Thermal Maximum (PETM), the GPTS2004 estimate is $1470 \mathrm{kyr}$ longer than in CK95. This discrepancy results from an $\sim 800$-kyr difference in the radiometric age for the same tuff in magnetochron $\mathrm{C} 21 \mathrm{n}(.33)$ (inverse stratigraphic position with respect to magnetochrons) and an $\sim 800$-kyr difference in the absolute age for the PETM (Fig. 8) (Machlus et al., 2004; Berggren et al., 1995; Ogg and Smith, 2004). As a result, the durations 


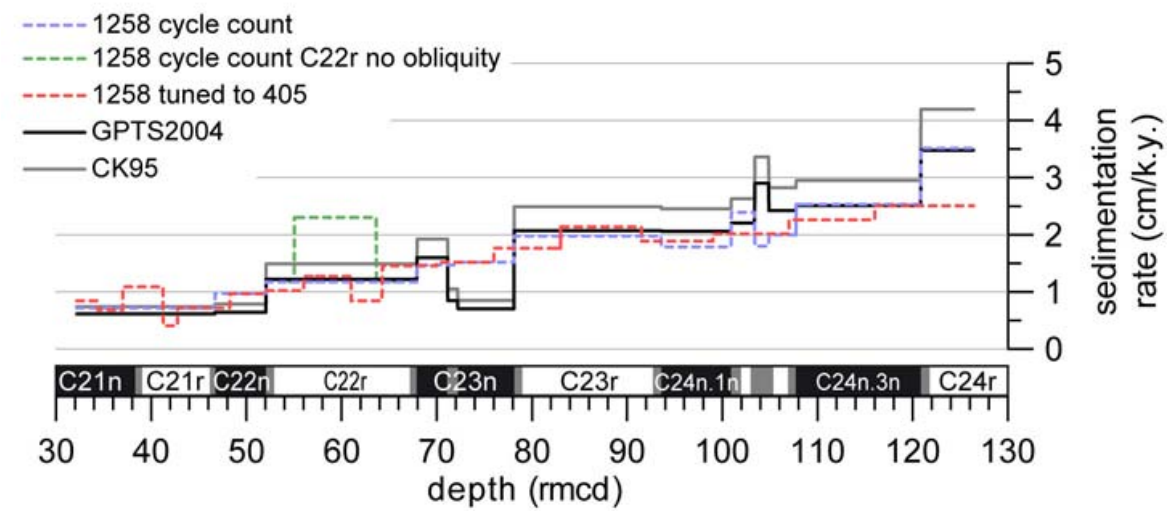

Fig. 7. Resulting sedimentation rates for the ODP Site 1258 record in $\mathrm{cm} / \mathrm{kyr}$ based on orbital tuning to the stable $405 \mathrm{yr}$ cycle (dash red), on cyclostratigraphy (dashed blue), on the Cande and Kent (1995) (CK95, gray) time scale and Geomagnetic Polarity Time Scale 2004 (GPTS2004, black) time scale plotted against depth (rmcd) and magnetostratigraphy. The sedimentation rate based on the unlikely assumption that the 42-cm cycles observed in Chron C22r are precession rather than obliquity cycles are also added (dashed green). For further explanation see text.

of magnetochrons between the calibration points are relatively longer in GPTS2004 compared to CK95 (Fig. 8a). The ODP Site 1258 record indicates that the interval from the onset of the PETM to the top of magnetochron C21r is $868 \mathrm{kyr}$ (1051 kyr) (first number from cycle counting, number in brackets from tuning to the stable 405-kyr cycle) longer than CK95, but $601 \mathrm{kyr}$ (419 kyr) shorter than GPTS2004. These new data point to an age for the $\mathrm{C} 2 \ln (.33)$ ash of somewhere between the values given by GPTS2004 (45.6 Ma) and CK95 (46.8 Ma). This implies that the age for the $\mathrm{C} 21 \mathrm{n}(.33)$ ash in GPTS2004 has to be slightly older, roughly $45.9 \mathrm{Ma}$. This would also fit to the proposed age for the FCT standard of 28.20 Ma rather than 28.02 Ma (Kuiper et al., 2004).

Our detailed analysis reveals additional differences between the timescales: e.g. Chron C24 in this study is $\sim 830$ kyr longer than in CK95 and $\sim 450$ kyr longer than in GPTS2004, which solely derives from the revised duration of Chron C24r (Westerhold et al., 2007). Magnetochron C23 seems to be $\sim 100 \mathrm{kyr}$ and $\sim 400 \mathrm{kyr}$ shorter than in CK95 and in GPTS2004, respectively, probably due to the much shorter normal C23n with a problematic top at Site 1258 (see Fig. 3). Alternatively, the rather large error in the width of C23 in the South Atlantic anomaly profile (Cande and Kent, 1995) of about $274 \mathrm{kyr}$ with respect to CK95 and $332 \mathrm{kyr}$ with respect to GPTS2004 could be the reason for the difference. Here, it is also important to note that the biggest stretch effect for spline-function calibrations occurs between two tiepoints, which in this case (roughly) coincides with C23n. Thus, the strong shift in sedimentation rates at Site 1258 calculated on CK95 and GPTS2004 ages (Fig. 7) might be a consequence of the overestimated C23n duration. Finally, magnetochrons $\mathrm{C} 22$ and $\mathrm{C} 21 \mathrm{r}$ also both seem to be longer than in CK95 but shorter than in GPTS2004. In general, the $\mathrm{C} 24 \mathrm{n}$ to $\mathrm{C} 20 \mathrm{n}$ interval seems to be a difficult interval as there are only anomaly profile records available with poor magnetochron assignments (see Table 4 in CK95).

\subsection{The role of the Green River chronostratigraphy}

Several ${ }^{40} \mathrm{Ar} /{ }^{39} \mathrm{Ar}$ ages derived from tuff horizons within the lacustrine Green River Formation of Wyoming (USA) have been generated in order to reevaluate and recalibrate the early Eocene part of the GPTS (e.g. Smith et al., 2003, 2004, 2006; ; Machlus et al., 2004; Wing et al., 1991). In combination with existing paleomagnetic and biostratigraphic records some of these radiometric ages were used to construct a chronostratigraphy for the Eocene Green River Formation. However, a consistent and reliable basin-wide chronostratigraphy for the Green River Formation does not exist as it is still difficult to correlate the available records in all detail (Smith et al., 2004; Clyde et al., 2004). Hence, a modification of the GPTS is proposed to resolve the dating dilemma of Clyde et al. (2001) in the Green River Formation (GR Fm) (Machlus et al., 2004). Based on the assumption that the single-crystal ${ }^{40} \mathrm{Ar} /{ }^{39} \mathrm{Ar}$ ages from the Sixth (6th) Tuff are time equivalents of the top of magnetochron C23n in the GR Fm, combined radiometric ages and published magnetostratigraphic constraints suggest that the magnetochron C22/C23 boundary is 1.5-2.5 myr too old in CK95 (Machlus et al., 2004; Smith et al., 2006) (Version C of Machlus et al., 2004 in Fig. 8).

Recently, the Green River chronostratigraphy has been refined based on a suite of twenty-two ${ }^{40} \mathrm{Ar} /{ }^{39} \mathrm{Ar}$ ages for ash beds in several different terrestrial basins (Smith et al., 2008a). Moreover, seven out of the twenty-two ${ }^{40} \mathrm{Ar} /{ }^{39} \mathrm{Ar}$ dated ash layers were identified within paleomagnetically characterized strata or their correlative equivalents (Table 4 in Smith et al., 2008a) and were used to recalibrate the early to middle Eocene GPTS (Fig. 8). The revision clearly 

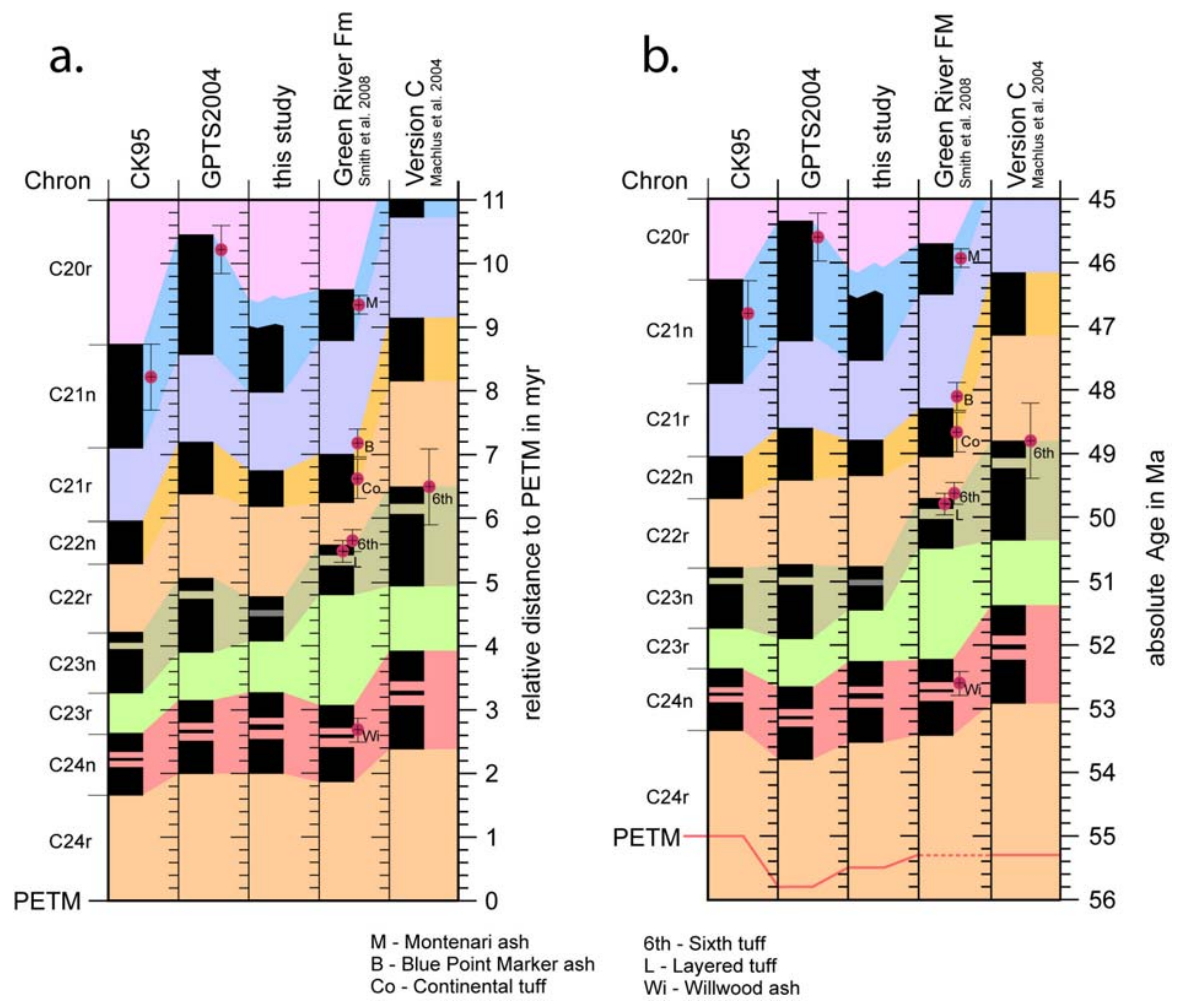

Fig. 8. Duration of magnetochrons from the Paleocene/Eocene boundary (Paleocene-Eocene Thermal Maximum, PETM). (a), Relative distance of magnetochron reversals to the PETM and (b), Absolute age (and distance) of magnetochron reversals based on the duration of magnetochrons published by Cande and Kent (1995) (CK95), Ogg and Smith (2004) (Geomagnetic Polarity Time Scale 2004 - GPTS2004), Machlus et al. (2004) (Version C), Smith et al. (2008a) (Green River Formation) and the new estimates based on the ODP Site 1258 cyclostratigraphy. The red dots (with 2 sigma error bars) mark the positions of the radiometric tie-points used by the respective study. For details about the ash layers see Smith et al. (2008a). Note that CK95 and GPTS2004 utilize the same ash layer in C21n (position is C21n.33) but with a different absolute age of $46.8 \pm 0.5 \mathrm{Ma}$ and $45.6 \pm 0.38 \mathrm{Ma}$, respectively. For further discussion see text.

shows that Version C of Machlus et al. (2004) overestimates the duration of magnetochrons $\mathrm{C} 23$ and $\mathrm{C} 22$ due to a tooyoung age estimate of the 6th tuff (Fig. 8). However, the revised chronostratigraphy of the GR Fm still suggests that the $\mathrm{C} 22 / \mathrm{C} 23$ boundary is 1.5 myr younger than in CK95 and also suggests a much longer duration for $\mathrm{C} 23 \mathrm{r}$.

Both the new results from ODP Site 1258 and the revised Eocene GPTS by Smith et al. (2008a) are consistent for C24n and roughly for $\mathrm{C} 22 \mathrm{n}$ with substantial differences for magnetochrons $\mathrm{C} 23 \mathrm{r}, \mathrm{C} 22 \mathrm{r}$, and 21r: magnetochrons $\mathrm{C} 23 \mathrm{r}$ and $\mathrm{C} 21 \mathrm{r}$ seem relatively stretched in Smith et al. (2008a) compared to the results derived at Site 1258. The duration of magnetochron $\mathrm{C} 22 \mathrm{r}$ is only less than half of our estimate (Table 2, Fig. 8). However, the comparison demonstrates that the absolute age calibration for magnetochron $\mathrm{C} 22 \mathrm{n}$ by ash layers from the GR Fm is consistent with our orbitally calibrated framework. Only the calibration of magnetochron $\mathrm{C} 23 \mathrm{n}$ for the GR Fm seems to be problematic. As applied by Machlus et al. (2004, Version C), the new chronostratigraphy for the GR Fm is based on the assumption that the single-crystal
${ }^{40} \mathrm{Ar} /{ }^{39} \mathrm{Ar}$ ages from the 6th Tuff are time equivalents of the top of Chron C23n. Due to the tentative correlation of tuff-containing intervals in the GR Fm and the potential diachrony between the basin center and margin (for discussion see Clyde et al., 1997, 2001, 2004; Machlus et al., 2004; Smith et al., 2003, 2004, 2006) we propose that the correlation of ash layers to magnetochron C23n in the GR Fm is highly questionable.

We have additional arguments to doubt the correlation of ash layers to magnetochron C23n in the GR Fm chronostratigraphy. The ODP Site 1258 chronology is based on the identification of the stable $405 \mathrm{kyr}$ eccentricity cycle. Three options are available for the absolute age of the PETM: $55.53,55.93$ or $56.33 \mathrm{Ma}$ (Westerhold et al., 2007, 2008). The PETM cannot be younger because then the complete Paleocene interval would have to be shifted to the younger. If we shift the PETM to younger estimates then the absolute age of the Cretaceous/Paleogene $(\mathrm{K} / \mathrm{Pg})$ boundary would be in strong conflict with recently established radiometric age estimates (Westerhold et al., 2008; Kuiper et al., 2008). If 
Table 2. Comparison of different estimates for the duration of magnetochrons C $21 \mathrm{n}$ to $\mathrm{C} 24 \mathrm{n}$.

\begin{tabular}{|c|c|c|c|c|c|c|c|c|c|}
\hline \multirow[t]{2}{*}{ Chron } & \multirow{2}{*}{$\begin{array}{l}\text { CK95 } \\
\text { (kyr) }\end{array}$} & \multirow{2}{*}{$\begin{array}{c}\text { GPTS2004 } \\
\text { (kyr) }\end{array}$} & \multirow{2}{*}{$\begin{array}{c}\text { Röhl et al. } \\
\text { (2003) } \\
\text { (kyr) }\end{array}$} & \multirow{2}{*}{$\begin{array}{c}\text { Smith et al. } \\
\text { (2008a) } \\
(\mathrm{kyr})\end{array}$} & \multicolumn{3}{|c|}{$\begin{array}{l}\text { Machlus et al. } \\
\text { (2004) }\end{array}$} & \multicolumn{2}{|c|}{ this study } \\
\hline & & & & & Version B & Version C & Version D & tuned $\mathrm{d}^{\dagger}(\mathrm{kyr})$ & cycle count \\
\hline $\mathrm{C} 21 \mathrm{n}$ & 1642 & 1889 & & 810 & 1930 & 2030 & 1740 & & \\
\hline $\mathrm{C} 21 \mathrm{r}$ & 1131 & 1364 & & 1780 & 1380 & 1570 & 1300 & $1265 \pm 40$ & $1235 \pm 48^{\#}$ \\
\hline $\mathrm{C} 22 \mathrm{n}$ & 677 & 828 & & 770 & 840 & 1000 & 800 & $638 \pm 58$ & $570 \pm 72^{\#}$ \\
\hline $\mathrm{C} 22 \mathrm{r}$ & 1064 & 1303 & 902 & 640 & 1310 & 1650 & 1300 & $1469 \pm 63$ & $1401 \pm 95^{\#}$ \\
\hline$C 23 n$ & 965 & 1171 & 738 & 790 & 1160 & 1560 & 1210 & $675 \pm 45$ & $683 \pm 63 \ddagger$ \\
\hline C $23 n .1 n$ & 168 & 202 & & 170 & 200 & 270 & 210 & $224 \pm 61$ & $226 \pm 68^{\ddagger}$ \\
\hline $\mathrm{C} 23 \mathrm{n} .1 \mathrm{r}$ & 101 & 125 & & 160 & 120 & 160 & 120 & $72 \pm 53$ & $74 \pm 53^{\ddagger}$ \\
\hline$C 23 n .2 n$ & 696 & 844 & & 460 & 840 & 1130 & 880 & $379 \pm 55$ & $399 \pm 63^{\ddagger}$ \\
\hline $\mathrm{C} 23 \mathrm{r}$ & 621 & 747 & 533 & 1730 & 740 & 1010 & 780 & $800 \pm 46$ & $798 \pm 63^{\ddagger}$ \\
\hline$C 24 n$ & 983 & 1159 & 1230 & 1210 & 1130 & 1550 & 1230 & $1299 \pm 42$ & $1260 \pm 53^{\ddagger}$ \\
\hline $\mathrm{C} 24 \mathrm{n} .1 \mathrm{n}$ & 299 & 355 & & 360 & 350 & 480 & 370 & $390 \pm 52$ & $389 \pm 63 \ddagger$ \\
\hline C24n.1r & 94 & 112 & & 120 & 110 & 150 & 120 & 125 & $105 \pm 32^{\ddagger}$ \\
\hline$C 24 n .2 n$ & 44 & 52 & & 40 & 50 & 70 & 50 & 75 & $84^{\ddagger}$ \\
\hline $\mathrm{C} 24 \mathrm{n} .2 \mathrm{r}$ & 102 & 119 & & 140 & 110 & 160 & 130 & 142 & $147 \pm 21^{\dagger}$ \\
\hline$C 24 n .3 n$ & 444 & 521 & & 550 & 510 & 560 & 560 & $567 \pm 37$ & $525 \pm 42 \ddagger$ \\
\hline
\end{tabular}

$\dagger$ tuned to the stable 405-kyr long eccentricity cycle

$\$$ assuming $21 \mathrm{kyr}$ for each precession cycle

\# assuming $95 \mathrm{kyr}$ for each short eccentricity cycle

the 6th Tuff did indeed coincide with the C23/C22 boundary, then the PETM and the K/Pg boundary would be 1.5 to 2 myr younger then recent estimates (Kuiper et al., 2008). This and the resulting stretch within $\mathrm{C} 23 \mathrm{r}$ (see Fig. 8b) seem to be rather unrealistic. Hence, the discrepancy might be related to either (1), the full propagated uncertainty of the radiometric ages of the ash layers in the GR Fm itself, or (2), the correlation between the South Pass and Bridger Basin sections (for discussion see Clyde et al., 2004) as well as the correlation to relevant ash layers (or the exact position of the Wasatchian/Bridgerian boundary). Correlation of the Smith et al. (2008a) ages with our cyclostratigraphy shows that the relative distances between the PETM and the top of C22n roughly agree (Fig. 8), therefore we assume that the uncertainty of the radiometric ages of the ash layers provided by Smith et al. (2008a) is not the reason for the discrepancy. The correlation of the 6th Tuff $(49.62 \pm 0.86 \mathrm{Ma})$ with full propagated uncertainty; Smith et al. (2008a) to the $\mathrm{C} 22 / \mathrm{C} 23$ boundary is much more challenging. If we apply the three alternative absolute age estimates for the PETM (Westerhold et al., 2008) in combination with the ODP Site 1258 cyclostratigraphy, then the $\mathrm{C} 22 / \mathrm{C} 23$ boundary would be $50.8 \mathrm{Ma}, 51.2 \mathrm{Ma}$, or $51.6 \mathrm{Ma}$. For the C21/C22 boundary we would obtain ages of $49.0 \mathrm{Ma}, 49.4 \mathrm{Ma}$ and $49.8 \mathrm{Ma}$, respectively. These results lead to the conclusion that the 6th Tuff can not be related to the $\mathrm{C} 22 / \mathrm{C} 23$ boundary because it is too young, even considering the full propagated uncertainty. In fact, the age estimates imply that the 6th
Tuff must be close to the C21/C22 boundary, which would agree with the interpretation that magnetochron $\mathrm{C} 23 \mathrm{n}$ might be missing in the lacustrine strata of the Tipton and Wilkins Peak Members (Smith et al., 2004). Applying the calibrated age of $28.201 \pm 0.046 \mathrm{Ma}$ for the FCT standard (Kuiper et al., 2008), the 6th Tuff would then become $\sim 0.65 \%$ older ( $\sim 49.94 \mathrm{Ma}$ ), which would be consistent with the cyclostratigraphic estimate of $49.8 \mathrm{Ma}$ for the $\mathrm{C} 21 / \mathrm{C} 22$ boundary using tuning option 3 of Westerhold et al. (2008). This is consistent with the revised age of the K/Pg boundary (Kuiper et al., 2008) of $65.95 \mathrm{Ma}$. Due to the uncertainty in the exact position of ash layers in the GR Fm in relation to the geomagnetic polarity pattern it is impossible to provide revised age calibrations of the ash layers in the GR Fm.

The dominant cyclicity in the GR Fm has recently been tested for its orbital origin (Machlus et al., 2008; Meyers, 2008). Orbital age models based on the tuning of oil-yield values from the Wilkins Peak Member of the lower Eocene GR Fm have been reported to overlap with ${ }^{40} \mathrm{Ar} /{ }^{39} \mathrm{Ar}$ dates (Machlus et al., 2008). Our results, although slightly different, are not in conflict with this interpretation because Machlus et al. (2008) are looking at relative age differences between ash layers (Smith et al., 2008a), which, as we demonstrated, roughly agree between the PETM and the top of magnetochron $\mathrm{C} 22 \mathrm{n}$. However, it will still be challenging to compare the oil-yield data with marine cyclic sedimentary successions in detail. 
Our study shows that the discrepancy between the GR Fm and the cyclostratigraphy at ODP Site 1258 is substantial. Due to the missing section in the GR Fm, which would contain both well-dated ash layers and good magnetostratigraphy, the calibration of early and middle Eocene paleomagnetic polarity records by ash layers from the GR Fm is problematic. However, we are confident that the astronomically calibrated stratigraphic framework from ODP Site 1258 for the early Eocene is robust, as we could clearly identify the stable long eccentricity cycle. Future challenges will be to solve the pending GR Fm internal stratigraphy and inconsistencies of pelagic marine cyclostratigraphy with radiometric dating.

\subsection{The end of the Early Eocene Climate Optimum - evidence for high-latitude influence at the beginning of the Cenozoic long-term cooling trend}

The early to middle Eocene Earth has been characterized as a greenhouse world with high $\mathrm{CO}_{2}$ concentrations in the atmosphere partly due to increased volcanic emissions (Pearson and Palmer, 2000; Royer et al., 2007). Global temperatures reached a long-term maximum with its climax within the 2 million year long Early Eocene Climatic Optimum (EECO; $\sim 53$ to $51 \mathrm{Ma}$ ) (Sloan and Rea, 1996; Zachos et al., 2008) (Fig. 9a). The termination of the EECO is globally expressed by the onset of increasingly cooler deep-water temperatures and marks the onset of the long-term cooling trend towards the icehouse world (Shackleton, 1986; Zachos et al., 2001). This trend has been attributed to the permanent removal of atmospheric $\mathrm{CO}_{2}$ by enhanced silicate weathering (Fig. 9a) (Raymo and Ruddiman, 1992; Walker et al., 1981; Smith et al., 2008b) and/or enhanced burial of organic carbon (FranceLanord and Derry, 1997). Recently, new oxygen-isotope records and tropical sea-surface temperature reconstructions have revealed that the cooling probably largely took place at higher latitudes (Pearson et al., 2007).

Boron-based $\mathrm{pH}$ reconstructions (Pearson and Palmer, 2000) indicate a relatively sudden drop in $p \mathrm{CO}_{2}$ values during the EECO within the interval between magnetochrons C24n.3n and C23n (Bralower and Mutterlose, 1995) (Fig. 9a). A lowering of the sea level (Miller et al., 2005) as well as an increase in deep-sea strontium isotope values (Hodell et al., 2007) both support the assumption of a decrease in volcanic $\mathrm{CO}_{2}$ outgassing. Subsequently, global deep-sea benthic oxygen-isotope records reflect the onset of the long-term cooling trend at the termination of the EECO (Zachos et al., 2001). All these facts indicate that the cooling trend was driven by the combined effects of both a decline of greenhouse gases due to weathering and a decrease in $\mathrm{CO}_{2}$ outgassing. However, at present the exact timing of the early to middle Eocene $p \mathrm{CO}_{2}$ drop is not known in detail as well as the relationships between greenhouse climates and $p \mathrm{CO}_{2}$ are not yet fully understood (Lowenstein and Demicco, 2006; Fletcher et al., 2008).
However, the low-latitude $\mathrm{Fe}$ intensity record from ODP Site 1258 adds important hints toward understanding the early to middle Eocene climate evolution. The cyclostratigraphy reveals that climatic cyclicity in the deep tropical Atlantic is strongly dominated by precession and eccentricity with the temporarily increased influence of orbital obliquity. Sedimentary records from both the South Atlantic (Walvis Ridge, ODP Leg 208) and the Northwest Pacific (Shatsky Rise, ODP Leg 198) covering the entire Paleocene and earliest Eocene are characterized by precession cycles modulated by eccentricity with virtually no apparent obliquity component (Röhl et al., 2007; Westerhold et al., 2007, 2008). Hence, the early Paleogene climate shows the clear imprint of orbital forcing, most likely through an influence on the carbon cycle as well as temperature (i.e. Shackleton, 2000; Pälike et al., 2006). The dominance of precession and eccentricity cycles as well as the almost absent obliquity component in most of these early Paleogene sedimentary records supports the idea that the overall influence of obliquity on global climate during ice-free periods without an icesheet amplifier might have been weaker (Zachos et al., 2001). The observed strong precession cycles might be related to the existence of a seasonal-cycle rectifier (e.g. Huybers and Wunsch, 2003).

For this reason it is very remarkable that we found strong obliquity cycles at ODP Site 1258 that lasted for a period of $\sim 800 \mathrm{kyr}$ in the middle of magnetochron $\mathrm{C} 22 \mathrm{r}$, right at the onset of the long-term cooling trend (Fig. 9b and Fig. S5). This phase coincides with a minimum in the very-long eccentricity cycle, an increase in benthic oxygen isotope values by $\sim 0.5 \%$, and a small shift in strontium isotope values. Apparent obliquity cycles at this low-latitude site probably point to a high-latitude influence on low-latitude climate and/or on deep ocean geochemistry.

A pair of closely spaced hiatuses in onshore New Jersey boreholes (ODP 150X), with the lower event eroding part of magnetochron C22r (Browning et al., 1997; their sequence E4), point to submarine erosion that took place in the North Atlantic about $50 \mathrm{Ma}$ ago. Indications for similar erosional events have been observed on Blake Nose (ODP Leg 171B) during the same time interval, and these were attributed to brief periods of intensified bottom currents (Norris et al., 2001). If the cooling at $\sim 50$ Ma took place only at high latitudes (Pearson et al., 2007), as e.g. reported from the Lomonossov Ridge in the Arctic Ocean (Stickley et al., 2008) and the Tasman Sea in the Southern Ocean (Brinkhuis et al., 2003), then the increased latitudinal temperature gradient might have caused stronger wind-driven ocean circulation and an intensification of bottom-water formation in high latitudes (Bice and Marotzke, 2001), and thus promoted the observed erosion patterns on the western Atlantic continental margin. Subsequent changes in ocean chemistry are indicated by CCD shoaling and carbonate accumulation collapse in the South Atlantic at $\sim 50 \mathrm{Ma}$ (Shipboard Scientific Party, 2004b). 


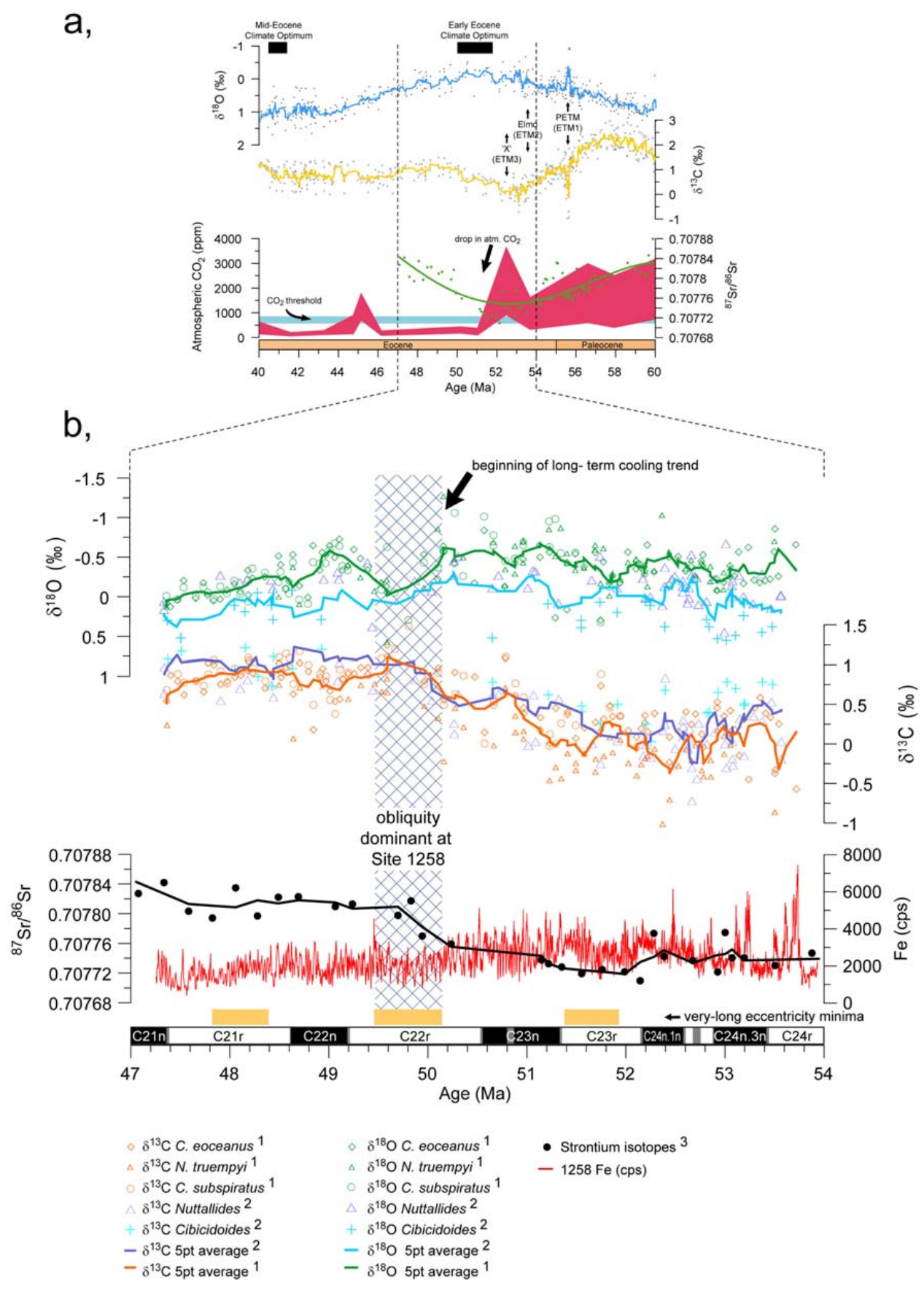

Fig. 9. Evolution of late Paleocene to middle Eocene climate. (a), global deep-sea oxygen and carbon isotope records (5-point running mean of Zachos et al., 2001), atmospheric $\mathrm{CO}_{2}$ (Pearson and Palmer, 2000), and Sr isotopes (Hodell et al., 2007). Also shown are the Early Eocene Climatic Optimum (EECO), the more transient Mid-Eocene Climatic Optimum (MECO), and hyperthermal events of the early Eocene such as the PETM (Paleocene-Eocene Thermal Maximum, ETM1), Elmo (ETM2), and X-event (ETM3). The blue bar indicates the $p \mathrm{CO}_{2}$ threshold between 2- and 3-times the pre-industrial level (PAL) where ice sheets may have formed (DeConto and Pollard, 2003a). (b), Zoom in from 54 to $47 \mathrm{Ma}$ showing deep-sea oxygen (upper panel) and carbon isotope (middle panel) records, and strontium isotope and Fe intensity record (lower panel). We also plotted the magnetostratigraphy of ODP Site 1258 as well as the intervals of minima in the very-long eccentricity cycle (orange bars) and the interval with dominant obliquity cycles. Note that isotope data have been collected on multiple species and converted to GPTS2004 (Ogg and Smith, 2004). Source of data: (1) Sexton et al. (2006), (2) Zachos et al. (2001), (3) Hodell et al. (2007). 
The question arises: why do we see pronounced obliquity cycles at deep sea Site 1258 in this particular period? The point could be raised that due to changes in sedimentation rate we have misinterpreted precession cycles as obliquity cycles in magnetochron C22r. But, if the sedimentary cycles with a period of $46 \mathrm{~cm}$ would be related to precession, sedimentation rates of $1-1.5 \mathrm{~cm} / \mathrm{kyr}$ before and after the designated interval would be twice as high within the interval, and be at $2-3 \mathrm{~cm} / \mathrm{kyr}$ (Fig. 7). Additionally, the duration of $\mathrm{C} 22 \mathrm{r}$ would be shortened by substantial $\sim 400 \mathrm{kyr}$. However, all the sedimentation rate estimates based on the GPTS, the persistent period of short eccentricity in the ODP Site 1258 sediments, and the relationship of Milankovitch cycles strongly argue against a doubling of sedimentation rates within this brief period in C22r. Nevertheles, we definitely can not proof the existence of a brief interval of increased sedimentation rates or alternatively a substantial gap in the sedimentary record of Site 1258 because no published deep sea record across Chron C22r is available. But there is no good reason other than assuming a smooth progression of the sedimentation rate. Therefore, we suggest that the dominant cycles in the middle of $\mathrm{C} 22 \mathrm{r}$ are obliquity related. From an orbital forcing perspective it is not surprising to observe a stronger obliquity component in long-eccentricity minima. Interestingly we have not identified a significant obliquity component for the other two periods of very-long eccentricity minima in the investigated ODP Site 1258 record (Fig. 9b). This might indicate that during the observed $800 \mathrm{kyr}$ period the amplitude of the obliquity component was particularly high. As current orbital solutions are still likely to be incorrect beyond $\sim 42$ Ma due to the chaotic diffusion in the solar system (Laskar et al., 2004), an accurate determination of successive minima in the very long eccentricity cycle (Westerhold et al., 2007) as well as the obliquity cycle itself is not possible for the period presented here. Another example of a similar orbital configuration with the combination of low eccentricity - high obliquity component can be found in the period from 3.0 to $2.3 \mathrm{Ma}$, in direct relation to the intensification of the Northern Hemisphere glaciation (Haug and Tiedemann, 1998). However, the low-latitude record of Site 1258 is very special because, unlike at high latitudes, local insolation forcing due to obliquity oscillations is quite small. Obliquity influences the relative strength of the seasons and it predominantly affects the high latitudes. Especially high-obliquity configurations increase insolation at latitudes above $45^{\circ}$ in both hemispheres and decreases the solar energy received in the tropics and subtropics (Liu and Herbert, 2004). In the absence of an ice-sheet, strong obliquity forcing might be amplified by moisture and heat transport in the atmosphere and ocean. Thus, strong obliquity cycles observed at Site 1258 indicate that, during an $800 \mathrm{kyr}$ interval, high-latitude processes driven by orbital obliquity might have dominated deep ocean chemistry in low latitudes. Ocean and atmospheric circulation could have transferred the high-latitude signal to low latitudes via stronger wind-driven ocean circulation and intensification of high-latitude bottom water formation.

Was it possible that ephemeral ice-sheets did exist on the poles at the termination of the EECO? More than three million years after the obliquity-dominated phase, at $\sim 46 \mathrm{Ma}$, the first occurrence of ice-rafted debris (IRD) in the central Arctic (Moran et al., 2006; Backman et al., 2008; St. John, 2008) slightly precedes the earliest evidence of ice found in the Antarctic so far (Moran et al., 2006; Backman et al., 2008; St. John, 2008). Glacial ice may have existed well before $46 \mathrm{Ma}$ during short intervals of orbitally driven insolation minima, even in some intervals during the Late Cretaceous to early Eocene (Miller et al., 2005; Pekar et al., 2005; Bornemann et al., 2008). Modeling results for the glaciation of Antarctica show that declining Cenozoic $p \mathrm{CO}_{2}$ may have played the dominant role (DeConto and Pollard, 2003b) in the initiation of large continental ice sheets on the poles. The first highly dynamic terrestrial ice sheets may have formed when a $p \mathrm{CO}_{2}$ threshold between 2- and 3-times the pre-industrial level (PAL) was crossed and orbital periods with cold austral summers prevailed (DeConto and Pollard, 2003a). For our example the proposed drop in $p \mathrm{CO}_{2}$ (Pearson and Palmer, 2000) might have crossed this threshold at the termination of the EECO (Fig. 9a). The special orbital configuration with the very-long eccentricity minimum and high-amplitude obliquity variations might have favored the nucleation of ephemeral ice sheets and/or favor the formation of extended sea-ice as early as $\sim 50 \mathrm{Ma}$ ago. Around $50 \mathrm{Ma}$ the first biosiliceous sediments appear at the Lomonossov Ridge in the Arctic Ocean (Backman and et al., 2008; Stickley et al., 2008) indicating lower sea-surface temperatures. There is not yet evidence for ephemeral ice on or sea-ice around Antarctica at $\sim 50 \mathrm{Ma}$. However, we found obliquity cycles at the deep sea ODP Site 1258 throughout the entire magnetochron $\mathrm{C} 21 \mathrm{r}$ interval, suggesting a continued high-latitude influence probably via deep ocean circulation beginning at $\sim 50 \mathrm{Ma}$.

If cooling was triggered by the drawdown of $p \mathrm{CO}_{2}$ where did all the carbon go? Biological sequestration of $\mathrm{CO}_{2}$, and thus enhanced burial of organic carbon, is observed in the Arctic Ocean sediments from PETM to the Azolla freshwater event ( $55-49 \mathrm{Ma}$ ) (Stein et al., 2006; Knies et al., 2008; Moran et al., 2006). The massive occurrence of the fresh-water fern Azolla confirms the presence of fresh surface-water conditions with cooler temperatures of $\sim 10^{\circ} \mathrm{C}$ (Brinkhuis et al., 2006). Associated fresh and relatively cool surface waters may have enabled winter ice formation, marking the start of a middle Eocene transition to a bipolar "icehouse" world (Moran et al., 2006). The termination of the Azolla phase occurred within magnetochron C21r but the onset is less well defined (Brinkhuis et al., 2006) (Fig. 9b). 


\section{Summary and conclusions}

Our chronology provides key data for calibration of the early Eocene interval of the Geomagnetic Polarity Time Scale (GPTS). Estimates for the duration of magnetochrons based on cyclostratigraphy of ODP Site 1258 refines the interpretations of Cande and Kent (1995) as well as the GPTS2004. The new results disprove the assumption based on radiometric ages and magnetostratigraphic constraints from the Green River Formation (Machlus et al., 2004; Smith et al., 2006) that the C22/C23 magnetochron boundary is $1.5-$ 2.5 myr younger than in CK95. We also demonstrate that the early Eocene GPTS calibrated by the new geochronology of the Green River Formation (Smith et al., 2008a) and the ODP Site 1258 cyclostratigraphy-based GPTS are not consistent to each other. This discrepancy might vanish once the correlation of ash layers to the geomagnetic polarity record in the Green River Formation can be clearly resolved.

Even more the high-resolution ODP Site 1258 record enables us to investigate the influence of Milankovitch forcing on climate variability in the early Eocene, and may provide us with important clues about the transition from the Early Eocene Climate Optimum into the Cenozoic long-term cooling trend. The early to middle Eocene climatic record is characterized by eccentricity-modulated precession cycles, except for a period of $\sim 800 \mathrm{kyr}$ within magnetochron $\mathrm{C} 22 \mathrm{r}$. This period exhibits strong obliquity cycles, which we interpret as the documentation of the increased influence of high-latitude processes on low latitude deep ocean chemistry at the termination of the EECO right at the onset of the long-term Cenozoic cooling trend. Reduced volcanic outgassing, in combination with enhanced silicate weathering and carbon storage in the North Polar area, could likely have caused a drop in atmospheric $\mathrm{CO}_{2}$ during the early Eocene. Subsequent cooling, preferentially at high latitudes, creating an increase in the latitudinal temperature gradient, resulted in stronger wind-driven ocean circulation, intensification of bottom-water formation in high latitudes, and thus be partly responsible for erosional features in deep-sea sediments. A specific orbital configuration with low eccentricity and high obliquity components - similar to what was identified at the time of intensification of the Northern Hemisphere glaciation - following the crossing of a critical $p \mathrm{CO}_{2}$ threshold between 2- and 3-times the pre-industrial level might have led to the formation of the first ephemeral ice sheet preferentially on Antarctica or at least extended sea-ice areas as early as 50.1 to $49.4 \mathrm{Ma}$ ago.

Acknowledgements. Funding for this research was provided by the Deutsche Forschungsgemeinschaft (DFG). We are grateful to J. Dinarès-Turell and an anonymous referee for their thorough reviews. We are indebted to H. Pfletschinger and V. Lukies (MARUM) for assisting in XRF core scanning, the staff at IODP Bremen Core Repository (BCR) for core handling, W. Hale for improving the English, and D. J. Thomas and W. C. Clyde for discussion. This research used samples and data provided by the Ocean Drilling
Program (ODP). ODP is sponsored by the US National Science Foundation (NSF) and participating countries under the management of Joint Oceanographic Institution (JOI) Inc. The complete data set presented in this paper is available online in the WDCMARE PANGAEA database under www.pangaea.de.

Edited by: L. Beaufort

\section{References}

Agnini, C., Muttoni, G., Kent, D. V., and Rio, D.: Eocene biostratigraphy and magnetic stratigraphy from Possagno, Italy: The calcareous nannofossil response to climate variability, Earth Planet. Sc. Lett., 241, 815-830, 2006.

Agnini, C., Fornaciari, E., Raffi, I., Rio, D., Röhl, U., and Westerhold, T.: High-resolution nannofossil biochronology of middle Paleocene to early Eocene at ODP Site 1262: Implications for calcareous nannoplankton evolution, Mar. Micropaleontol., 64, 215-248, 2007.

Backman, J., Jakobsson, M., Frank, M., Sangiorgi, F., Brinkhuis, H., Stickley, C. E., O’Regan, M., Lovlie, R., Pälike, H., Spofforth, D., Gattacecca, J., Moran, K., King, J., Heil, C.: Age model and core-seismic integration for the Cenozoic Arctic Coring Expedition sediments from the Lomonosov Ridge, Paleoceanography, 23, PA1S03, doi:10.1029/2007PA001476, 2008.

Berggren, W. A., Kent, D. V., Swisher III, C. C., and Aubry, M. P.: A revised Cenozoic geochronology and chronostratigraphy., in: Geochronology, Time Scales and Global Stratigraphic Correlation, edited by: Berggren, W. A., Kent, D. V., Aubry, M. P., and Hardenbol, J., SEPM, Spec. Publ., 129-212, 1995.

Bice, K. L. and Marotzke, J.: Numerical evidence against reversed thermohaline circulation in the warm Paleocene/Eocene ocean, J. Geophys. Res., 106, 11529-11542, 2001.

Bornemann, A., Norris, R. D., Friedrich, O., Beckmann, B., Schouten, S., Damste, J. S. S., Vogel, J., Hofmann, P., and Wagner, T.: Isotopic Evidence for Glaciation During the Cretaceous Supergreenhouse, Science, 319, 189-192, doi:10.1126/science.1148777, 2008.

Bralower, T. J. and Mutterlose, J.: Calcareous Nannofossil Biostratigraphy of Site 865, Allison Guyot, Central Pacific Ocean: A Tropical Paleogene Referencs Section, in: Proc. ODP, Sci. Results, edited by: Winterer, E. L., Sager, W. W., Firth, J. V., and Sinton, J. M., 143, 31-74, 1995.

Brinkhuis, H., Warnaar, J., Huber, M., Zachos, J. C., McCarren, H. K., Röhl, U., Westerhold, T., and Zachos, J. C.: The end of the Early Eocene Climatic Optimum: Evidence for Concomitant Cooling of Southern Ocean Surface Waters and Global Deep Waters From Dinoflagellate Endemism, Eos. Trans. AGU, Fall Meeting, 84 (46), Abstract PP31B-0252, 2003.

Brinkhuis, H., Schouten, S., Collinson, M. E., Sluijs, A., Damsté, J. S. S., Dickens, G. R., Huber, M., Cronin, T. M., Onodera, J., Takahashi, K., Bujak, J. P., Stein, R., van der Burgh, J., Eldrett, J. S., Harding, I. C., Lotter, A. F., Sangiorgi, F., Cittert, H. v. K.-v., de Leeuw, J. W., Matthiessen, J., Backman, J., Moran, K., and Expedition 302 Scientists: Episodic fresh surface waters in the Eocene Arctic Ocean, Nature, 441, 606-609, 2006.

Browning, J. V., Miller, K. G., Van Fossen, M., Liu, C., Pak, D. K., Aubry, M.-P., and Bybell, L. M.: Early to middle Eocene sequences of the New Jersey coastal plain and their significance 
for global climate change, in: Proc. ODP, Sci. Results, 150X: College Station, TX (Ocean Drilling Program), edited by: Miller, K. G. and Snyder, S. W., 229-242, 1997.

Cande, S. C. and Kent, D. V.: A New Geomagnetic Polarity Time Scale for the late Cretaceous and Cenozoic, J. Geophys. Res., 97, 13917-13951, 1992.

Cande, S. C. and Kent, D. V.: Revised calibration of the geomagnetic polarity timescale for the Late Cretaceous and Cenozoic, J. Geophys. Res., 100, 6093-6095, 1995.

Clyde, W. C., Zonneveld, J.-P., Stamatakos, J., Gunnell, Y., and Bartels, W. S.: Magnetostratigraphy across the Wasatchian/Bridgerian NALMA Boundary (Early to Middle Eocene) in the Western Green River Basin, Wyoming, J. Geol., 150, 657-669, 1997.

Clyde, W. C., Sheldon, N. D., Koch, P. L., Gunnell, G. F., and Bartels, W. S.: Linking the Wasatchian/Bridgerian boundary to the Cenozoic Global Climate Optimum: new magnetostratigraphic and isotopic results from South Pass, Wyoming, Palaeogeogr. Palaeocl., 167, 175-199, 2001.

Clyde, W. C., Bartels, W. S., Gunnell, G. F., and Zonneveld, J.P.: 40Ar/39Ar geochronology of the Eocene Green River Formation, Wyoming: Discussion, Geol. Soc. Am. Bull., 116, 251-252, 2004.

DeConto, R. M. and Pollard, D.: A coupled climate-ice sheet modeling approach to the Early Cenozoic history of the Antarctic ice sheet, Palaeogeogr. Palaeocl., 198, 39-52, 2003 a.

DeConto, R. M. and Pollard, D.: Rapid Cenozoic glaciation of Antarctica induced by declining atmospheric $\mathrm{CO}_{2}$, Nature, 421, 245-249, 2003b.

Erbacher, J., Mosher, D. C., Malone, M. J., et al.: Proc. ODP, Init. Repts., 207, available at: http: //www-odp.tamu.edu/publications/207_IR/207ir.htm doi: 10.2973/odp.proc.ir.207.2004, 2004.

Fletcher, B. J., Brentnall, S. J., Anderson, C. W., Berner, R. A., and Beerling, D. J.: Atmospheric carbon dioxide linked with Mesozoic and early Cenozoic climate change, Nat. Geosci, 1, 43-48, 2008.

France-Lanord, C. and Derry, L. A.: Organic carbon burial forcing of the carbon cycle from Himalayan erosion, Nature, 390, 65-67, 1997.

Ghil, M., Allen, M. R., Dettinger, M. D., Ide, K., Kondrashov, D., Mann, M. E., Robertson, A. W., Saunders, A., Tian, Y., Varadi, F., and Yiou, P.: Advanced Spectral Methods for Climatic Time Series, Rev. Geophys., 40(1), 1003, doi:10.1029/2001RG000092, 2002.

Gradstein, F., Ogg, J., and Smith, A.: A Geological Timescale 2004, Cambridge University Press, 2004.

Haug, G. and Tiedemann, R.: Effect of the formation of the Isthmus of Panama on Atlantic Ocean thermohaline circulation, Nature, 393, 673-676, 1998.

Hay, W. W., DeConto, R., Wold, C. N., Wilson, K. M., Voigt, S., Schulz, M., Wold-Rossby, A., Dullo, W.-C., Ronov, A. B., Balukhovsky, A. N., and Soeding, E.: Alternative Global Cretaceous Paleogeography, in: The Evolution of Cretaceous Ocean/Climate Systems, edited by: Barrera, E. and Johnson, C., Geol. S. Am. S., 1-47, 1999.

Herbert, T. D., Premoli-Silva, I., Erba, E., and Fischer, A. G.: Orbital Chronology of Cretaceous-Paleocene Marine Sediments, in: Geochronology, Time Scales and Global Stratigraphic
Correlation, edited by: Berggren, W. A., Kent, D. V., Aubry, M. P., and Hardenbol, J., SEPM, Spec. Publ., 54, 81-93, 1995.

Hinnov, L. A. and Ogg, J. G.: Cyclostratigraphy and the Astronomical Time Scale, Stratigraphy, 4, 239-251, 2007.

Hodell, D. A., Kamenov, G. D., Hathorne, E. C., Zachos, J. C., Röhl, U., and Westerhold, T.: Variations in the strontium isotope composition of seawater during the Paleocene and early Eocene from ODP Leg 208 (Walvis Ridge), Geochem. Geophy. Geosy., 8, Q09001, doi:10.1029/2007GC001607, 2007.

Huybers, P. and Wunsch, C.: Rectrification and precession signals in the climate system, Geophys. Res. Lett., 30, 2011, doi:2010.1029/2003GL017875, 2003.

Knies, J., Mann, U., Popp, B. N., Stein, R., and Brumsack, H.-J.: Surface water productivity and paleoceanographic implications in the Cenozoic Arctic Ocean, Paleoceanography, 23, PA1S16, doi:10.1029/2007PA001455, 2008.

Kuiper, K. F., Hilgen, F. J., Steenbrink, J., and Wijbrans, J. R.: 40Ar/39Ar ages of tephras intercalated in astronomically tuned Neogene sedimentary sequences in the Mediterranean, Earth Planet. Sc. Lett., 222, 583-597, 2004.

Kuiper, K. F., Deino, A., Hilgen, F. J., Krijgsman, W., Renne, P. R., and Wijbrans, J. R.: Synchronizing Rock Clocks of Earth History, Science, 320, 500-504, doi:10.1126/science.1154339, 2008.

Laskar, J., Robutel, P., Joutel, F., Gastineau, M., Correia, A., and Levrard, B.: A long-term numerical solution for the insolation quantities of the Earth, Astron. Astrophys., 428, 261-285, 2004.

Lear, C. H., Elderfield, H., and Wilson, P. A.: Cenozoic Deep-Sea Temperatures and Global Ice Volumes from $\mathrm{Mg} / \mathrm{Ca}$ in Benthic Foraminiferal Calcite, Science, 287, 269-272, 2000.

Liu, Z. and Herbert, T. D.: High-latitude influence on the eastern equatorial Pacific climate in the early Pleistocene epoch, Nature, 427, 720-723, doi:10.1038/nature02338, 2004.

Lourens, L. J., Sluijs, A., Kroon, D., Zachos, J. C., Thomas, E., Röhl, U., Bowles, J., and Raffi, I.: Astronomical pacing of late Palaeocene to early Eocene global warming events, Nature, 435, 1083-1087, 2005.

Lowenstein, T. K. and Demicco, R. V.: Elevated Eocene Atmospheric $\mathrm{CO}_{2}$ and Its Subsequent Decline, Science, 313, 1928, doi:10.1126/science.1129555, 2006.

Luterbacher, H. P., Ali, J. R., Brinkhuis, H., Gradstein, F. M., Hooker, J. J., Monechi, S., Ogg, J. G., Powell, J., Röhl, U., Sanfilippo, A., and Schmitz, B.: The Paleogene Period, in: A Geological Timescale 2004, edited by: Gradstein, F., Ogg, J., and Smith., A., 384-408, 2004.

Machlus, M., Hemming, S. R., Olsen, P. E., and Christie-Blick, N.: Eocene calibration of geomagnetic polarity time scale reevaluated: Evidence from the Green River Formation of Wyoming, Geology, 32, 137-140, 2004.

Machlus, M. L., Olsen, P. E., Christie-Blick, N., and Hemming, S. R.: Spectral analysis of the lower Eocene Wilkins Peak Member, Green River Formation, Wyoming: Support for Milankovitch cyclicity, Earth Planet. Sc. Lett., 268, 64-75, 2008.

Mann, M. E. and Lees, J. M.: Robust estimation of background noise and signal detection in climatic time series, Climatic Change, 33, 409-445, 1996.

Meyers, S. R.: Resolving Milankovitchian controversies: The Triassic Latemar Limestone and the Eocene Green River Formation, Geology, 36, 319-322, 2008. 
Miller, K. G., Kominz, M. A., Browning, J. V., Wright, J. D., Mountain, G. S., Katz, M. E., Sugarman, P. J., Cramer, B. S., ChristieBlick, N., and Pekar, S. F.: The Phanerozoic Record of Global Sea-Level Change, Science, 310, 1293-1298, 2005.

Moran, K., Backman, J., Brinkhuis, H., Clemens, S. C., Cronin, T., Dickens, G. R., Eynaud, F. d. r., Gattacceca, J. r. m., Jakobsson, M., Jordan, R. W., Kaminski, M., King, J., Koc, N., Krylov, A., Martinez, N., Matthiessen, J., McInroy, D., Moore, T. C., Onodera, J., O’Regan, M., Pälike, H., Rea, B., Rio, D., Sakamoto, T., Smith, D. C., Stein, R., St. John, K., Suto, I., Suzuki, N., Takahashi, K., Watanabe, M., Yamamoto, M., Farrell, J., Frank, M., Kubik, P., Jokat, W., and Kristoffersen, Y.: The Cenozoic palaeoenvironment of the Arctic Ocean, Nature, 441, 601-605, 2006.

Norris, R. D., Klaus, A., and Kroon, D.: Mid-Eocene deep water, the Late Palaeocene Thermal Maximum and continental slope mass wasting during the Cretaceous-Palaeogene impact, Geological Society, London, Special Publications, 183, 23-48, doi:10.1144/gsl.sp.2001.183.01.02, 2001.

Ogg, J. G. and Smith, A. G.: The geomagnetic polarity time scale, in: A Geological Timescale 2004, edited by: Gradstein, F., Ogg, J., and Smith, A., Cambridge University Press, 63-86, 2004.

Pälike, H., Norris, R. D., Herrle, J. O., Wilson, P. A., Coxall, H. K., Lear, C. H., Shackleton, N. J., Tripati, A. K., and Wade, B. S.: The Heartbeat of the Oligocene Climate System, Science, 314, 1894-1898, doi:10.1126/science.1133822, 2006.

Pearson, P. N. and Palmer, M. R.: Atmospheric carbon dioxide concentrations over the past 60 million years, Nature, 406, 695-699, 2000.

Pearson, P. N., van Dongen, B. E., Nicholas, C. J., Pancost, R. D., Schouten, S., Singano, J. M., and Wade, B. S.: Stable warm tropical climate through the Eocene Epoch, Geology, 35, 211-214, doi:10.1130/g23175a.1, 2007.

Pekar, S. F., Hucks, A., Fuller, M., and Li, S.: Glacioeustatic changes in the early and middle Eocene (51-42 Ma): Shallowwater stratigraphy from ODP Leg 189 Site 1171 (South Tasman Rise) and deep-sea d18O records, Geol. Soc. Am. Bull., 117, 1081-1093, 2005.

Raymo, M. E. and Ruddiman, W. F.: Tectonic forcing of late Cenozoic climate, Nature, 359, 117-122, 1992.

Richter, T. O., Van der Gast, S., Koster, R., Vaars, A., Gieles, R., De Stigter, H. C., De Haas, H., and Van Weering, T. C. E.: The Avaatech XRF Core Scanner: technical description and applications to NE Atlantic sediments, in: New Techniques in Sediments Core Analysis, edited by: Rothwell, R. G., Geological Society London, Special Publication, London, 39-51, 2006.

Röhl, U. and Abrams, L. J.: High-Resolution, Downhole and NonDestructive Core Measurements from Sites 999 and 1001 in the Caribbean Sea: Application to the Late Paleocene Thermal Maximum, in: Proc. ODP, Sci. Results, edited by: Leckie, R. M., Sigurdsson, H., Acton, G. D., and Draper, G., 165, 191-203, 2000.

Röhl, U., Norris, R. D., and Ogg, J. G.: Cyclostratigraphy of upper Paleocene and lower Eocene sediments at Blake Nose Site 1051 (western North Atlantic), in: Causes and Consequences of Globally Warm Climates in the Early Paleogene, edited by: Wing, S. L., Gingerich, P. D., Schmitz, B., and Thomas, E., Geol. S. Am. S., Boulder: Colorado, 576-589, 2003.

Röhl, U., Westerhold, T., Monechi, S., Thomas, E., Zachos, J. C., and Donner, B.: The Third and Final Early Eocene Thermal Maximum: Characteristics, Timing and Mechanisms of the " $\mathrm{X}$ " Event, Geol. Soc. Am. Abstracts with Programs, paper no.: 1172, 37(7), 264, 2005.

Röhl, U., Westerhold, T., Bralower, T. J., and Zachos, J. C.: On the duration of the Paleocene-Eocene thermal maximum (PETM), Geochem. Geophy. Geosy., 8, Q12002, doi:10.1029/2007GC001784, 2007.

Röhl, U., Westerhold, T., Thomas, E., Monechi, S., and Donner, B.: New focus on the early Eocene Greeenhouse World: rates and dates of ancient global warming events or what makes the $\mathrm{X}$ event special, Geophys. Res. Abstr., 11, EGU2009-4218, 2009.

Royer, D. L., Berner, R. A., and Park, J.: Climate sensitivity constrained by $\mathrm{CO}_{2}$ concentrations over the past 420 [thinsp]million years, Nature, 446, 530-532, 2007.

Sexton, P. F., Wilson, P. A., and Norris, R. D.: Testing the Cenozoic multisite composite $\delta 18 \mathrm{O}$ and $\delta 13 \mathrm{C}$ curves: New monospecific Eocene records from a single locality, Demerara Rise (Ocean Drilling Program Leg 207), Paleoceanography, 21(2), Pa2019, doi:10.1029/2005PA001253, 2006.

Shackleton, N. J.: Paleogene stable isotope events, Palaeogeography, Palaeoclimatology, Palaeoecology, 57, 91-102, 1986.

Shackleton, N. J.: The 100.000-Year Ice-Age Cycle Identified and Found to Lag Temperature, Carbon Dioxide, and Orbital Eccentricity, Science, 289, 1897-1902, doi:10.1126/science.289.5486.1897, 2000.

Shipboard Scientific Party: Site 1258, in: Proc. ODP, Init. Repts., 207: College Station, TX (Ocean Drilling Program), edited by: Erbacher, J., Mosher, D. C., Malone, M. J., et al., 1-117, doi:110.2973/odp.proc.ir.2207.2105.2004, 2004a.

Shipboard Scientific Party: Leg 208 summary, in: Proc. ODP, Init. Repts. 208, edited by: Zachos, J. C., Kroon, D., Blum, P., et al., 1-112 [CD-ROM], available from: Ocean Drilling Program, Texas A\&M University, USA, College Station TX 77845-79547, 2004b.

Sloan, L. C. and Rea, D. K.: Atmospheric carbon dioxide and early Eocene climate: A general circulation modeling sensitivity study, Palaeogeography, Palaeoclimatology, Palaeoecology, 119, 275292, 1996.

Smith, M. E., Singer, B., and Carroll, A.: 40Ar/39Ar geochronology of the Eocene Green River Formation, Wyoming, GSA Bulletin, 115, 549-565, 2003.

Smith, M. E., Singer, B. S., and Carroll, A. R.: Reply, Geol. Soc. Am. Bull., 116, 253-256, 2004.

Smith, M. E., Singer, B., Carroll, A., and Fournelle, J. H.: Highresolution calibration of Eocene strata: 40Ar/39Ar geochronology of biotite in the Green River Formation, Geology, 32, 393 396, doi:10.1130/G22265.1, 2006.

Smith, M. E., Carroll, A. R., and Singer, B. S.: Synoptic reconstruction of a major ancient lake system: Eocene Green River Formation, western United States, Geol. Soc. Am. Bull., 120, 54-84, 2008a.

Smith, E. M., Carroll, A. R., and Mueller, E. R.: Elevated weathering rates in the Rocky Mountains during the Early Eocene Climatic Optimum, Nat. Geosci., 1, 370-374, 2008 b.

St. John, K.: Cenozoic ice-rafting history of the central Arctic Ocean: Terrigenous sands on the Lomonosov Ridge, Paleoceanography, 23, PA1S05, doi:10.1029/2007PA001483, 2008.

Stein, R., Boucsein, B., and Meyer, H.: Anoxia and high primary 
production in the Paleogene central Arctic Ocean: First detailed records from Lomonosov Ridge, Geophys. Res. Lett., 33, L18606, doi:10.1029/2006GL026776, 2006.

Stickley, C. E., Koç, N., Brumsack, H.-J., Jordan, R. W., and Suto, I.: A siliceous microfossil view of middle Eocene Arctic paleoenvironments: A window of biosilica production and preservation, Paleoceanography, 23, PA1S14, doi:10.1029/2007PA001485, 2008.

Suganuma, Y. and Ogg, J. G.: Campanian through Eocene magnetostratigraphy of Sites 1257-1261, ODP Leg 207, Demerara Rise (western equatorial Atlantic), in: Proc. ODP, Sci. Results, 207, available at: http://www-odp.tamu.edu/publications/ 207_SR/102/102.htm, edited by: Mosher, D. C., Erbacher, J., and Malone, M. J., 2006.

Tjallingii, R., Röhl, U., Kölling, M., and Bickert, T.: Influence of the water content on X-ray fluorescence core scanning measurements in soft marine sediments, Technical Brief, Geochem. Geophy. Geosy., 8, Q02004, doi:10.1029/2006GC001393, 2007.

Varadi, F., Runnegar, B., and Ghil, M.: Successive Refinements in Long-Term Integrations of Planetary Orbits, Astrophys. J., 592, 620-630, 2003.

Wade, B. S. and Pälike, H.: Oligocene climate dynamics, Paleoceanography, 19, PA4019, doi:4010.1029/2004PA001042, 2004.

Walker, J. C. G., Hays, P. B., and Kasting, J. K.: A negative feedback mechanism for the long term stabilization of Earth's surface temperature, J. Geophys. Res., 86, 9776-9782, 1981.
Weedon, G. P.: The recognition and stratigraphic implications of orbital-forcing of climate and sedimentary cycles, in: Sedimentology Review, edited by: Wright, V. P., Wiley-Blackwell, 1, 3150, 1993.

Weedon, G. P.: Time-series Analysis and Cyclostratigraphy, Cambridge University Press, 2003.

Westerhold, T., Röhl, U., Laskar, J., Bowles, J., Raffi, I., Lourens, L. J., and Zachos, J. C.: On the duration of magnetochrons $\mathrm{C} 24 \mathrm{r}$ and $\mathrm{C} 25 \mathrm{n}$ and the timing of early Eocene global warming events: Implications from the Ocean Drilling Program Leg 208 Walvis Ridge depth transect, Paleoceanography, 22, PA2201, doi:10.1029/2006PA001322, 2007.

Westerhold, T., Röhl, U., Raffi, I., Fornaciari, E., Monechi, S., Reale, V., Bowles, J., and Evans, H. F.: Astronomical calibration of the Paleocene time, Palaeogeography, Palaeoclimatology, Palaeoecology, 257, 377-403, doi:10.1016/j.palaeo.2007.09.016, 2008.

Wing, S. L., Brown, T. M., and Obradovich, J. D.: Early Eocene biotic and climatic change in interior western North America, Geology, 19, 1189-1192, 1991.

Zachos, J., Pagani, M., Sloan, L., Thomas, E., and Billups, K.: Trends, Rhythms, and Aberrations in Global Climate $65 \mathrm{Ma}$ to Present, Science, 292, 686-693, 2001.

Zachos, J. C., Dickens, G. R., and Zeebe, R. E.: An early Cenozoic perspective on greenhouse warming and carbon-cycle dynamics, Nature, 451, 279-283, 2008. 